\title{
A systematic review of the relationship between severe maternal morbidity and post-traumatic stress disorder
}

\author{
Marie Furuta ${ }^{1 *}$, Jane Sandall ${ }^{2}$ and Debra Bick ${ }^{1}$
}

\begin{abstract}
Background: The incidence of severe maternal morbidity is increasing in high-income countries as a consequence, in part, of increased obstetric intervention and increasingly complex medical needs of women who become pregnant. Access to emergency obstetric care means that for the majority of women in these countries, an experience of severe maternal morbidity is unlikely to result in loss of life. However, little is known about the subsequent impact on postnatal psychological health resulting in an evidence gap to support provision of appropriate care for these women. There has recently been increasing recognition that childbirth can be a cause of post-traumatic stress disorder (PTSD). The combination of experiencing a life-threatening complication and its management may culminate in psychological trauma. This systematic review examined the association between women's experience of severe maternal morbidity during labour, at the time of giving birth or within the first week following birth, and PTSD and its symptoms.

Methods: Relevant literature was identified through multiple databases, including MEDLINE, PsycINFO, EMBASE, CINAHL, British Nursing Index, Web of Science, Cochrane library and the British Library, using predetermined search strategies. The search terms included "post-traumatic stress disorder", "PTSD", "stress disorders, post-traumatic", "maternal morbidity", "pregnancy complications" "puerperal disorders", "obstetric labo(u)r complication", "postpartum h(a)emorrhage", "eclampsia". Studies identified were categorised according to pre-defined inclusion and exclusion criteria. The quality of included studies was assessed using the relevant CASP appraisal tools.

Results: Eleven primary studies met review criteria. Evidence of a relationship between severe maternal morbidity and PTSD/PTSD symptoms was inconsistent and findings varied between studies. Nevertheless, there is some evidence that severe pre-eclampsia is a risk factor for PTSD and its symptoms, an association possibly mediated by other factors such as fetal/neonatal condition.

Conclusions: Despite the absence of robust evidence regarding the relationship between severe maternal morbidity and PTSD/PTSD symptoms, it is crucially important that clinicians and policy makers are aware of a potential higher risk of PTSD among women who experience severe morbidity. Further studies are now needed to confirm this risk as well as to understand underlying mechanisms in order to minimise the longer term psychiatric impact of severe maternal morbidity.
\end{abstract}

Keywords: PTSD, Childbirth, Posttraumatic stress, Obstetric labor complication, Pregnancy complications, Puerperal disorders

\footnotetext{
* Correspondence: marie.furuta@kcl.ac.uk

'King's College London, Florence Nightingale School of Nursing and Midwifery, James Clerk Maxwell Building, 57 Waterloo Road, London SE1 8WA, UK

Full list of author information is available at the end of the article
} 


\section{Background}

Post-traumatic stress disorder (PTSD) is a condition an individual may develop in response to experiencing or witnessing a highly traumatic event. According to the Diagnostic and Statistical Manual of Mental Disorder Fourth Edition (DSM-IV-TR) criteria for PTSD, it involves a typical subjective response such as intense fear, helplessness, or horror. Symptoms of PTSD include hyperarousal, intrusion/re-experiencing, and avoidance/numbing [1] (see Table 1). Although the concept of PTSD was initially applied to survivors of combat, rape and assault, it has increasingly been acknowledged that childbirth can be a cause of PTSD $[2,3]$. The prevalence following childbirth is estimated to be around $3 \%$ to $6 \%$ at around six weeks postpartum, decreasing to around $1.5 \%$ at 6 months postpartum [4]. Whether the prevalence of PTSD is higher in a postnatal population than the general population is unclear, but PTSD during the postpartum period is an important public health issue because of the longer-term negative impact of maternal mental health problems on child development [5-7] including impaired mother-infant relationship [8,9], delayed intellectual development $[10,11]$ and psychiatric disorder in children [12]. Long-term maternal morbidity, if not identified or appropriately managed at early stage, could also increase use of health care services by women and their families [13,14]. In one US general population study, Kessler (2000) reported that costs of PTSD to society are substantial because of individual life course consequences such as childbearing issues, marital instability and work loss, the main factors influencing welfare dependency in Western societies. Kessler suggested early outreach and treatment could help to reduce the enormous burden of PTSD to individuals and society [15].

Earlier reviews of PTSD following childbirth [2-4, 16,17] identified a number of factors associated with PTSD and PTSD symptoms including pregnancy and pre-existing factors, delivery related factors and postevent environmental factors. Pregnancy and pre-existing factors include tocophobia (fear of labour), depressive symptoms during pregnancy, history of psychiatric and psychological problems, primiparity, unplanned pregnancy, trait anxiety, history of sexual trauma, low selfefficacy and perception of low support. Labour and delivery related risk factors include mode of birth (i.e. emergency caesarean, instrumental delivery), partner not present, perception of low support from partner or staff, care factors (e.g. feeling poorly informed), high fear for self and/or baby, feelings of loss of control (powerlessness), negative gap between expectation and experience of severe pain. Post-event risk factors include the absence of available postnatal support and 'additional stress coping' [2-4,17]. Little attention has been paid to understanding whether a woman experiencing a potentially life threatening health event during her pregnancy, labour, birth or immediate postnatal period is more likely to develop PTSD, resulting in an evidence gap to support provision of appropriate care for these women.

The primary aim of this review was therefore to assess the evidence systematically regarding a potential relationship between severe maternal morbidity occurring during pregnancy, labour and birth until the end of the first week postpartum and onset of postnatal PTSD.

\section{Definition, incidence and prevalence of severe maternal morbidity}

'Severe maternal morbidity' (sometimes referred to as 'nearmiss') is now used as a marker of the quality of maternity care in many counties $[18,19]$. These two terms are often used interchangeably for a severe, life threatening complication [20]. The term 'near-miss' is, however, one of the binary outcomes of life-threatening complications, as an alternative to 'death' and only used when a woman survives the complication, implying a positive outcome when looking at the event retrospectively [21]. Conversely, 'severe morbidity' can be seen as a process towards either survival or death [21]. Vais and Bewley [22] also argued the difference between a 'near-miss' and 'severe maternal morbidity', pointing out the inappropriateness of using the term 'near miss' to refer to the morbidity a woman actually suffers. They stated that "the term 'near-miss' is no longer used, as this concept was originally derived from the aviation industry and referred more to risk management than the effect on the women" (p.340) [22]. Similarly, in the WHO conceptual framework for the international classification for patient safety [23], a near-miss is more related to medical error and defined as an incident which did not reach the patient (e.g. a unit of blood being given to the wrong patient, but the error detected before transfusion commenced). When considering women's actual experiences and the subsequent impact of obstetric complication on their psychiatric functions, it seems appropriate to use the term 'severe maternal morbidity' rather than 'near-miss'.

There is no universally applicable definition of severe maternal morbidity because the severity of the condition is often determined by multiple factors such as a woman's general health status, availability and accessibility of medical treatment, as well as human and technical resources in the healthcare system in a specific setting [21,22]. Although criteria to measure severe morbidity vary from study to study, Vais and Bewley [22] suggested that these criteria can be categorised into: 1) an organ system approach; and 2) a management or processbased approach. Say et al. [24] further categorised the organ system approach into two groups: 1) diseasespecific; and 2) organ system dysfunction/failure. Using a combination of these approaches, data on fourteen major maternal morbidity outcomes are audited each 
Table 1 DSM-IV-TR criteria for PTSD [1]

\begin{tabular}{|c|c|}
\hline \multirow[t]{3}{*}{ A } & Stressor \\
\hline & $\begin{array}{l}\square \text { The person has experienced, witnessed, or been confronted with an event or events that involve actual or threatened death or } \\
\text { serious injury, or a threat to the physical integrity of oneself or others. }\end{array}$ \\
\hline & $\square$ The person's response involved intense fear, helplessness, or horror \\
\hline \multirow[t]{6}{*}{ B } & Intrusive recollection (1 or more) \\
\hline & $\square$ Recurrent and intrusive distressing recollections of the event, including images, thoughts, or perceptions. \\
\hline & $\square$ Recurrent distressing dreams of the event \\
\hline & $\square$ Acting or feeling as if the traumatic event were recurring \\
\hline & $\square$ Intense psychological distress at exposure to internal or external cues that symbolize or resemble an aspect of the traumatic event \\
\hline & $\square$ Physiologic reactivity upon exposure to internal or external cues that symbolize or resemble an aspect of the traumatic event \\
\hline \multirow[t]{8}{*}{ C } & Avoidant/numbing (3 or more) \\
\hline & $\square$ Efforts to avoid thoughts, feelings, or conversations associated with the trauma \\
\hline & $\square$ Efforts to avoid activities, places, or people that arouse recollections of the trauma \\
\hline & $\square$ Inability to recall an important aspect of the trauma \\
\hline & $\square$ Markedly diminished interest or participation in significant activities \\
\hline & $\square$ Feeling of detachment or estrangement from others \\
\hline & $\square$ Restricted range of affect \\
\hline & $\square$ Sense of foreshortened future \\
\hline \multirow[t]{6}{*}{ D } & Hyper-arousal (2 or more) \\
\hline & $\square$ Difficulty falling or staying asleep \\
\hline & $\square$ Irritability or outbursts of anger \\
\hline & $\square$ Difficulty concentrating \\
\hline & $\square$ Hyper-vigilance \\
\hline & $\square$ Exaggerated startle response \\
\hline \multirow[t]{2}{*}{ E } & Duration \\
\hline & $\square$ Duration of the disturbance (symptoms in B, C, and D) is more than one month \\
\hline $\mathbf{F}$ & Functional significance \\
\hline & $\square$ The disturbance causes clinically significant distress or impairment in social, occupational, or other important areas of functioning \\
\hline
\end{tabular}

month as part of the Scottish Confidential Audit of Severe Morbidity [25], including major obstetric haemorrhage, eclampsia, renal or liver dysfunction, and septicaemic shock (see Table 2). Major obstetric haemorrhage (estimated blood loss $>=2500 \mathrm{ml}$ ) has been the most frequent cause of severe morbidity in Scotland with a statistically significant and steady upward trend in incidence from 2003 to 2006 of 3.5 and 6.3 per 1000 births respectively. The rate has fallen slightly in the past 2 years, but there has been an overall increase in incidence of postpartum haemorrhage in the UK as in many other developed countries [26,27]. There is no clear cut-off to distinguish between 'moderate' and 'severe' postpartum haemorrhage. Waterstone et al. [18] used an alternative cut-off (estimated blood loss $>1500 \mathrm{ml}$ ) to estimate the incidence of severe haemorrhage in South East Thames region in England which showed an incidence of 6.7 per 1000 deliveries in 1997/1998 (see Table 2 for Waterstone et al's criteria).

Retrospective register-based studies in Canada, Finland and the USA have also highlighted increasing rates of severe maternal morbidity [28]. For example, a retrospective Canadian cohort study using an national database, which involved a large sample of women $(n=2,548,824)$ who gave birth in hospitals between 1991 and 2000, observed considerable increases in the incidence of haemorrhage requiring hysterectomy (RR 1.8; 95\%CI 1.5-2.1), venous thromboembolism (RR1.7; 95\% CI 1.3-2.2), uterine rupture (RR1.6; 95\%CI 1.4-1.8), pulmonary oedema (RR2.1; 95\% CI 1.6-2.7), myocardial infarction (RR3.7; 95\%CI 1.2-11.4), adult respiratory distress syndrome (RR1.5; 95\% CI 1.1-2.1) and assisted ventilation (RR2.5; 95\% CI 1.9-3.2) during the study period. In the same Canadian population, the presence of major pre-existing chronic disease (e.g. diabetes and heart disease) increased the risk of severe maternal morbidity 6-fold [19]. Although criteria used to measure severe maternal morbidity varied between studies, there was also a trend in the rise in the overall rate of severe maternal morbidity in the US [29] and Finland [30] showing an increase from 4.5 per 1000 births in 19911994 to 5.9 in $1999-2003$ and from 5.9 in 1997 to 7.6 in 
Table 2 Criteria and definitions of severe maternal morbidity

Scottish Confidential Audit's criteria and definition [27]

1 Major obstetric haemorrhage

Estimated blood loss $\geq 2500 \mathrm{ml}$, or transfused 5 or more units of blood or received treatment for coagulopathy

2 Eclampsia

Seizure associated with antepartum, intrapartum or postpartum symptoms and signs of pre-eclampsia.

3 Renal or liver dysfunction

Acute onset of biochemical disturbance, urea $>15 \mathrm{mmol} / \mathrm{l}$, creatinine $>400 \mathrm{mmol} / \mathrm{l}$, AST/ALT $>200 \mathrm{u} / \mathrm{l}$.

4 Cardiac arrest

No detectable major pulse.

5 Pulmonary oedema

Clinically diagnosed pulmonary oedema associated with acute breathlessness and $\mathrm{O}_{2}$ saturation $<95 \%$, requiring $\mathrm{O}_{2}$, diuretics or ventilation.

6 Acute respiratory dysfunction Requiring intubation or ventilation for $>60$ minutes (not including duration of general anaesthetic).

7 Coma Including diabetic coma. Unconscious for $>12$ hours.

8 Cerebro-vascular event

Stroke, cerebral/cerebellar haemorrhage or infarction, subarachnoid haemorrhage, dural venous sinus thrombosis.

9 Status epilepticus

Unremitting seizures in patient with known epilepsy.

10 Anaphylactic shock

An allergic reaction resulting in collapse with severe hypotension, difficulty breathing and swelling/rash.

\section{Septicaemic shock}

Shock (systolic blood pressure $<80 \mathrm{~mm} / \mathrm{Hg}$ ) in association with infection. No other cause for decreased blood pressure.

Pulse of 120 beats/minute or more.

12 Anaesthetic problem

Aspiration, failed intubation, high spinal or epidural anaesthetic

\section{Massive pulmonary embolism}

Increased respiratory rate (> 20/min), tachycardia, hypotension. Diagnosed as 'high' probability on V/Q scan or positive spiral chest CT scan.

Treated by heparin, thrombolysis or embolectomy

\section{Intensive care admission/ Coronary care admission}

Unit equipped to ventilate adults. Admission for one of the above problems or for any other reason. Include CCU admissions.

\section{Waterstone et al's criteria and definition [18]}

\section{Severe preeclampsia}

Blood pressure 170/110 mm Hg on two occasions 4 hours apart or $>170 / 110 \mathrm{~mm} \mathrm{Hg}$ once plus $\geq 0.3 \mathrm{~g}$ in 24 hours proteinuria or $\geq++$ on dipstick

$\mathrm{OR}$

Diastolic blood pressure $>90 \mathrm{~mm} \mathrm{Hg}$ plus proteinuria (as above) on one occasion plus one of the following signs/symptoms:

Oliguria (<30 ml/h for 2 hours), Visual disturbances (flashing lights or blurred vision), Epigastric/right upper quadrant pain or tenderness, Thrombocytopenia $\left(<100 \times 10^{9}\right.$ /l) Pulmonary oedema

\section{Eclampsia}

Convulsions during pregnancy or in the first 10 days postpartum together with at least two of the following features within 24 hours after the convulsions: Hypertension ( $\geq 170 / 110 \mathrm{~mm} \mathrm{Hg}$ ), Proteinuria ( $\geq+$ on random dipstick analysis or $\geq 0.3 \mathrm{~g}$ in 24 hours)

Thrombocytopenia $\left(<100 \times 10^{9} /\right)$, Increased aspartate aminotransferase $(\geq 42 \mathrm{U} / \mathrm{I})$

\section{HELLP syndrome}

Haemolysis (abnormal peripheral smear or raised total bilirubin concentration $(\geq 20.5 \mu \mathrm{mol} / \mathrm{l})$ ), raised liver enzyme activity (raised aspartate aminotransferase $(\geq 70 \mathrm{U} / \mathrm{l})$ or raised $y$ glutamyltransferase $(\geq 70 \mathrm{U} / \mathrm{I})$, and low platelets $\left(<100 \times 10^{9} / \mathrm{I}\right)$ )

4 Severe haemorrhage Estimated blood loss $>1500 \mathrm{ml}$, peripartum fall in haemoglobin concentration $\geq 40 \mathrm{~g} / \mathrm{l}$ or acute transfusion of 4 or more units of blood

\section{Severe sepsis}

Sepsis is systemic response to infection manifested by two or more of: Temperature $>38^{\circ} \mathrm{C}$ or $<36^{\circ} \mathrm{C}$ (unless after prolonged caesarean), Heart rate $>100$ beats $/$ minute, Respiratory rate $>20 / \mathrm{min}$ or $\mathrm{PaCO}_{2}<32 \mathrm{mmHg}$, White cell count $>17 \times 10^{9} / \mathrm{I}$ or $<4 \times 10^{9} / \mathrm{l}$ or $>10 \%$ immature forms, Plus bacteraemia (that is, positive blood cultures) or positive swab culture 


\section{Table 2 Criteria and definitions of severe maternal morbidity (Continued)}

Severe sepsis is sepsis associated with one of: Organ dysfunction—for example, acute renal failure, Hypoperfusion—for example, lactic acidosis, oliguria, or acute alteration in mental state, Hypotension — that is, systolic blood pressure $<90 \mathrm{~mm} \mathrm{Hg}$ or drop of $>40 \mathrm{~mm} \mathrm{Hg}$ in the absence of other causes of hypotension

6 Uterine rupture

Acute dehiscence of the uterus leading to the emergency delivery of the infant

2002, respectively. The risk factors identified were slightly different between studies. In the US study, severe morbidity was more common at the extremes of reproductive age and among black women compared to white women, while caesarean birth (both emergency and elective) carried a significantly higher risk of lifethreatening maternal complications than vaginal birth in Finland [30]; these outcomes are likely to reflect context and models of care. Changes in the demographic characteristics of women who become pregnant in Western counties are likely to lead to even higher rates of morbidity in the future as highlighted by van Roosmalen and Zwart [28] and Knight [31]. Pregnant women are more likely to be overweight or obese and many women are delaying childbirth with the potential to develop chronic health conditions needing greater medical management during pregnancy and labour, leading to increase in perinatal complications $[28,31,32]$. In addition to the impact of severe maternal morbidity on a woman's physical health and well-being, it is essential to understand the magnitude of the potential impact on her mental health and well-being.

\section{Methods}

To examine the relationship between severe maternal morbidity and postnatal PTSD, three specific review questions were developed:

1) Is there a difference in prevalence or incidence of PTSD/PTSD symptoms between women who experienced severe maternal morbidity and those who did not?

2) Is there a statistical relationship between severe maternal morbidity and PTSD/PTSD symptoms, and if so, how strong is that relationship? and

3) Does the type of severe maternal morbidity affect the relationship between severe maternal morbidity and PTSD/PTSD symptoms?

Relevant literature were identified through electronic bibliographic databases; MEDLINE, PsycINFO, EMBASE, CINAHL, British Nursing Index (BNI), Web of Science, and Cochrane library. $\mathrm{PhD}$ theses were searched from the British Library. The search strategy was developed in consultation with an information specialist. The search terms included "post-traumatic stress disorder", "PTSD", "stress disorders, post-traumatic", "psychological distress", "traumatic stress" "traumatic delivery" and "birth trauma". Although the concept of "birth trauma" includes physical injuries, birth trauma in the context of this review refers to psychological trauma as suggested by Beck [33]. Keywords related to outcomes were searched in combination with search terms related to the exposure including "maternal morbidity", "pregnancy complications" "puerperal disorders", "obstetric labo(u)r complication", "postpartum h(a)emorrhage", "hysterectomy", "eclampsia", "pre-eclampsia", "HELLP syndrome" and "uterine rupture". The term "multiple organ failure" and terms for each criteria used in the Scottish Confidential Audit of Severe Maternal Morbidity (Table 2) such as "pulmonary (o)edema" and "coma" were also used in combination with the term to specify the population such as "pregnancy", "delivery, obstetric", "labo(u)r, obstetric", "birth", "parturition", "childbirth", "postpartum" and "postnatal". Subject headings (e.g $\mathrm{MeSH}$ ) and free-text terms were used to maximize the sensitivity of the search. Terms were modified when necessary as each database used slightly different thesaurus terms. Restrictions were made to publications from January 1970 to August 2011 and only studies published in English were included. The year 1970 was selected because understanding of the effects of trauma on psychotic symptoms dates back to at least the 1970s [34,35] which contributed to the official introduction of PTSD into the DSM-III in 1980 [36]. All studies identified in the electronic search were first assessed for relevance by reviewing the titles, abstracts and descriptor/MeSH terms. At this stage, each study was rated as "probably relevant", "of uncertain relevance" or "irrelevant" using the inclusion/exclusion criteria listed below. Studies rated as "probably relevant" or "of uncertain relevance" were further assessed with the full texts. The electronic search was supplemented by a manual search of the reference lists in all "potentially relevant" studies. Searches were completed on Aug 2011 and updated on June 2012.

\section{Inclusion and exclusion criteria}

The inclusion and exclusion criteria for this review are outlined in Table 3.

\section{Data extraction}

Initial screening was conducted by the primary reviewer (MF). The inclusion of the studies was discussed with 
Table 3 Inclusion and exclusion criteria

\begin{tabular}{|c|c|c|}
\hline Topic & Inclusion criteria & Exclusion criteria \\
\hline \multirow[t]{5}{*}{ Research focus } & \multirow{5}{*}{$\begin{array}{l}\text { - The relationship between severe maternal morbidity } \\
\text { that occurred during pregnancy until the end of the first week } \\
\text { postpartum and the onset of PTSD/PTSD symptoms within } \\
2 \text { years postpartum }\end{array}$} & $\begin{array}{l}\text { - Studies of PTSD/PTSD symptoms associated with } \\
\text { miscarriage and abortion }\end{array}$ \\
\hline & & $\begin{array}{l}\text { - Studies of PTSD/PTSD symptoms associated with } \\
\text { medical procedure or medical intervention per se } \\
\text { (e.g. caesarean section) without including severe } \\
\text { maternal morbidity as a predictor of PTSD/PTSD symptoms }\end{array}$ \\
\hline & & - Other postnatal psychological and physical problems \\
\hline & & $\begin{array}{l}\text { - Studies of PTSD/PTSD symptoms in pregnant women not } \\
\text { associated with pregnancy related events but with others } \\
\text { such as conflict, accidents or natural disasters }\end{array}$ \\
\hline & & $\begin{array}{l}\text { - Studies examining the effects of pre-existing PTSD/PTSD } \\
\text { symptoms on future pregnancies }\end{array}$ \\
\hline Population & $\begin{array}{l}\text {-Women who experienced (severe) maternal morbidity } \\
\text { (eg. Major obstetric haemorrhage, pre-eclampsia/eclampsia, } \\
\text { HELLP syndrome, admission to intensive/special care unit) }\end{array}$ & $\begin{array}{l}\text { Childbearing women in general (of whom, women who } \\
\text { experienced severe maternal morbidity not distinguishable) }\end{array}$ \\
\hline Setting/countries & - No restriction made & - None \\
\hline \multirow[t]{4}{*}{ Study type/design } & - Observational studies & - Descriptive studies with no comparison group \\
\hline & - Experimental studies with relevant data & - Qualitative studies \\
\hline & \multirow{2}{*}{$\begin{array}{l}\text { - Systematic reviews which examined the relationship } \\
\text { between severe maternal morbidity and subsequent } \\
\text { postnatal PTSD/PTSD symptoms }\end{array}$} & - Letter, commentary, news or short communications \\
\hline & & - Repeated findings originated from same study \\
\hline Language & • English & - Non-English \\
\hline Publication & - Published and grey literature & - None \\
\hline Time frame & - Studies published from 1970 & - Studies published before 1970 \\
\hline
\end{tabular}

associate reviewers (DB and JS) until consensus was reached. To support the critical appraisal of the methodological quality of each selected study, the Critical Appraisal Skills Programme (CASP) tools were used [37]. The review process and presentation complied with the PRISMA 2009 checklist [38] (Additional file 1 Appendix 1).

\section{Results}

The search of the electronic bibliographic databases identified 2085 studies. Of these, 697 were excluded after using the bibliographic software programme, Endnote (version X4), to identify duplicate articles. Initial screening based on a review of the titles, abstracts and keywords revealed 1298 studies not relevant on the basis of inclusion/exclusion criteria (e.g. examined physical birth trauma, ineligible population) or were unobtainable (e.g. unpublished $\mathrm{PhD}$ thesis which were not available online). Full-text versions were obtained for the remaining 90 studies and an additional 11 studies were identified manually (total 102). After careful consideration, 90 studies were excluded. Reasons included that 1) there was no variable of maternal morbidity in analysis, 2) studies assessed different or broad dimensions of psychological and/or physical problems following maternal morbidity, 3) maternal morbidity was clustered together with other variables (e.g. socio-demographic, previous miscarriages) and not analysed separately, 4) maternal morbidity appeared to be assessed but no statistical data were provided, 5) studies reported or indicated the possibility of PTSD following maternal morbidity but the association between these two variables was not examined, 6) PTSD was assessed in pregnancy or the effects of pre-existing PTSD on pregnancy complications (e.g. miscarriage) were examined, 7) qualitative/case reports, 8) irrelevant population 9) letter, commentary, news or short communications and 10) repeated findings originated from same study (published and unpublished) with the less informative publications excluded. Fourteen systematic or narrative reviews were identified that looked at PTSD/PTSD symptoms during pregnancy or following childbirth or obstetric interventions. All studies included in these reviews were retrieved, but none provided relevant data for this review, except for the study by Ayers (1999). A total of eleven studies were included in our review. The study selection process is presented in Figure 1 and excluded studies are listed in Appendix 2 (Additional file 2).

\section{Overview of selected studies}

The characteristics of the eleven included studies are summarised in Table 4. Studies originated from Netherlands $(\mathrm{n}=5)$, Australia $(\mathrm{n}=1)$, Canada $(\mathrm{n}=1)$, the UK $(\mathrm{n}=1)$, the US $(n=1)$, Israel $(n=1)$ and Nigeria $(n=1)$. There were six prospective cohort studies [39-44], two retrospective cohort studies $[45,46]$ and three cross-sectional cohort studies [47-49]. Four cohort studies primarily aimed to 


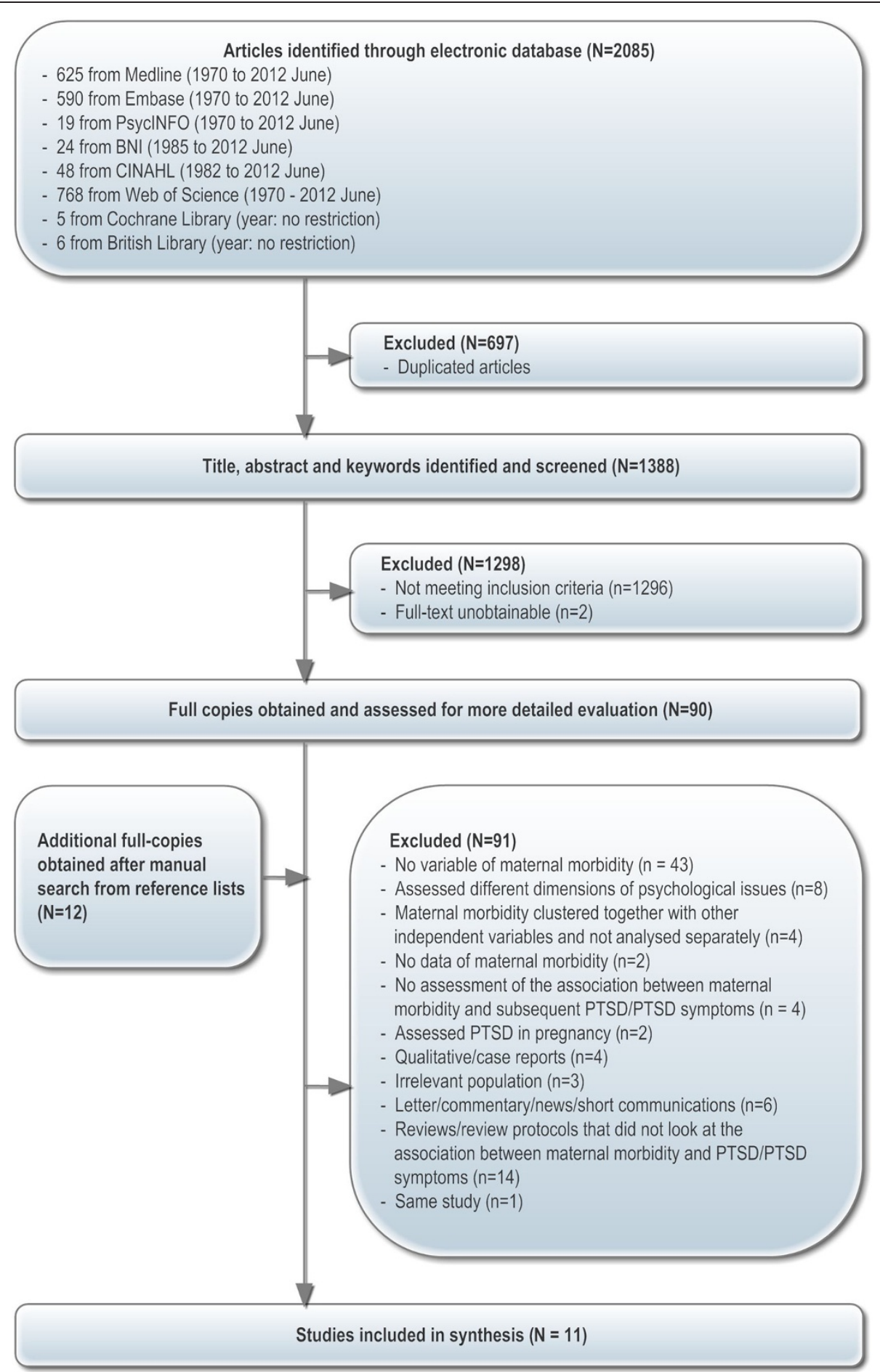

Figure 1 Quantitative study selection.

examine PTSD or PTSD symptoms following maternal morbidity or 'difficult' birth $[40,42,44,46]$. Four studies (two prospective cohorts and two cross-sectional) aimed to look at the prevalence and contributing factors related to PTSD or PTSD symptoms following childbirth in general $[39,41,47,48]$. Three studies (two cohorts and one cross-sectional) originally aimed to examine the effect of other exposure of interest (i.e. delivery settings, past traumatic events) or different outcomes (i.e. cognitive function) but reported relevant data for this review $[43,45,49]$. 
Table 4 Characteristic of the included studies

\begin{tabular}{|c|c|c|c|c|c|c|c|c|c|c|c|c|c|}
\hline \multirow[t]{2}{*}{ Authors } & \multirow[t]{2}{*}{ Country } & \multirow[t]{2}{*}{ Design } & \multirow[t]{2}{*}{ Site } & \multirow{2}{*}{$\begin{array}{l}\text { Size }^{\dagger} \\
\text { (follow-up) }\end{array}$} & \multirow{2}{*}{$\begin{array}{l}\text { Resp }_{\dot{ }} \\
\text { Rate }^{\dagger} \%\end{array}$} & \multirow{2}{*}{$\begin{array}{l}\text { Time of } \\
\text { recruitment }\end{array}$} & \multicolumn{2}{|c|}{ Criteria } & \multirow{2}{*}{\multicolumn{2}{|c|}{$\begin{array}{l}\text { Maternal morbidity type } \\
\text { (Data source) }\end{array}$}} & \multicolumn{3}{|c|}{ PTSD } \\
\hline & & & & & & & Inclusion & Exclusion & & & Time & Tool & Administration \\
\hline $\begin{array}{l}\text { Adewuya et } \\
\text { al. } 2006\end{array}$ & Nigeria & $\begin{array}{l}\text { Cross- } \\
\text { sectional }\end{array}$ & $\begin{array}{l}\text { Multi. clinic. } \\
(n=5)\end{array}$ & 876 & $95^{\mathrm{a}}$ & Postnatal & $\begin{array}{l}\text { Women attending } 6 \\
\text { week postnatal \& } \\
\text { infant immunisation } \\
\text { clinic }\end{array}$ & None & $\begin{array}{l}\text { Hospital admission } \\
\text { in pregnancy } \\
\text { Manual removal of } \\
\text { placenta }\end{array}$ & Self-report & 6 wks & M.I.N.I. & Interview \\
\hline $\begin{array}{l}\text { Ayers } 1999 \\
\text { (PhD thesis) }\end{array}$ & UK & $\begin{array}{l}\text { Pros. } \\
\text { cohort }\end{array}$ & $\begin{array}{l}\text { Single } \\
\text { hospital }\end{array}$ & $245(201)$ & $\begin{array}{l}70-83^{c} \\
\left(46-56^{\mathrm{a}}\right)\end{array}$ & Antenatal & $\begin{array}{l}\text { Gestational age } \\
16 \leq, \leq 36 \text { wks at } \\
\text { recruitment Good } \\
\text { English }\end{array}$ & $\begin{array}{l}\text { ElCS Poor English } \\
\text { Other research } \\
\text { participation } \\
\text { Moving out No } \\
\text { fixed address } \\
\text { Psychiatric inpatient }\end{array}$ & $\begin{array}{l}\text { Blood loss Delivery } \\
\text { complication }\end{array}$ & $\begin{array}{l}\text { Clinical } \\
\text { records }\end{array}$ & $\begin{array}{l}1 \text { week } 6 \\
\text { weeks } 6 \\
\text { mths }\end{array}$ & IES PSS-SR & Postal \\
\hline $\begin{array}{l}\text { Baecke } \\
\text { et al. } 2009\end{array}$ & Netherlands & $\begin{array}{l}\text { Retro. } \\
\text { cohort }\end{array}$ & $\begin{array}{l}\text { Single } \\
\text { hospital }\end{array}$ & 169 & $48-76^{b}$ or $c$ & Postnatal & $\begin{array}{l}\text { Pregnancy } \\
\text { complicated by } \\
\text { preeclampsia and } \\
\text { control groups }\end{array}$ & Multiple pregnancy & $\begin{array}{l}\text { Pre-term } \\
\text { preeclampsia Term } \\
\text { preeclampsia }\end{array}$ & $\begin{array}{l}\text { Clinical } \\
\text { records }\end{array}$ & $6-18$ mths & IES & Postal \\
\hline $\begin{array}{l}\text { Cohen et al. } \\
2004\end{array}$ & Canada & $\begin{array}{l}\text { Pros. } \\
\text { cohort }\end{array}$ & $\begin{array}{l}\text { Multi. } \\
\text { hospital } \\
(n=6)\end{array}$ & 198 & $60-87^{b}$ or $c$ & Postnatal & $\begin{array}{l}\text { Age } \geq 18 \text { Understand } \\
\text { English Delivered a } \\
\text { full-term Singleton } \\
\text { infant }\end{array}$ & $\begin{array}{l}\text { Poor English Child } \\
\text { for adoption Risk of } \\
\text { baby (multiple } \\
\text { infant, premature, } \\
\text { congenanomaly, } \\
\text { NICU, death) }\end{array}$ & $\begin{array}{l}\text { maternal } \\
\text { complications (PPH, } \\
\text { uterine infection } \\
\text { UTI, or retained } \\
\text { placenta etc.) }\end{array}$ & Not clear & 6-8 wks & DTS & $\begin{array}{l}\text { Interview } \\
\text { (telephone) }\end{array}$ \\
\hline $\begin{array}{l}\text { Creedy } \\
1999 \text { (PhD } \\
\text { thesis) }\end{array}$ & Australia & $\begin{array}{l}\text { Pros. } \\
\text { cohort }\end{array}$ & $\begin{array}{l}\text { Multi. } \\
\text { hospital } \\
(n=4)\end{array}$ & 499 (141) & $73^{b}$ & Antenatal & $\begin{array}{l}\text { Age } \geq 18 \text { 3rd } \\
\text { trimester pregnancy } \\
\text { Understand English } \\
\text { No major prenatal } \\
\text { complication No } \\
\text { medical problems } \\
\text { healthy full-term } \\
\text { infant }\end{array}$ & $\begin{array}{l}\text { Risk of baby } \\
\text { (premature, } \\
\text { stillbirth) Pregnancy } \\
\text { with high risk for } \\
\text { birth complications }\end{array}$ & $\begin{array}{l}\text { Delivery } \\
\text { complication (PPH, } \\
\text { anaemia, infection, } \\
\text { severe post-delivery } \\
\text { pain or manual } \\
\text { removal of placenta } \\
\text { etc) }\end{array}$ & Self-report & $\begin{array}{l}4-6 \text { wks } \\
3-4 \text { mths }\end{array}$ & IES PSS- & $\begin{array}{l}\text { Interview } \\
\text { (telephone) }\end{array}$ \\
\hline $\begin{array}{l}\text { Engelhard } \\
\text { et al. } 2002^{\ddagger}\end{array}$ & Netherlands & $\begin{array}{l}\text { Retro. } \\
\text { cohort }\end{array}$ & $\begin{array}{l}\text { Single } \\
\text { hospital }\end{array}$ & 113 & $51-90^{b}$ & Postnatal & $\begin{array}{l}\text { Pregnancy } \\
\text { complicated by } \\
\text { preeclampsia and } \\
\text { control groups } \\
\text { Primiparas }\end{array}$ & $\begin{array}{l}\text { Age }<18 \text {, Illiterate in } \\
\text { Dutch Intrauterine } \\
\text { fetal death }\end{array}$ & $\begin{array}{l}\text { Pre-term } \\
\text { preeclampsia Term } \\
\text { preeclampsia }\end{array}$ & $\begin{array}{l}\text { Clinical } \\
\text { records }\end{array}$ & $\leq 2 \mathrm{yrs}$ & PSS-SR & Postal \\
\hline $\begin{array}{l}\text { Hoedjes } \\
\text { et al., } 2001\end{array}$ & Netherlands & $\begin{array}{l}\text { Pros. } \\
\text { cohort }\end{array}$ & $\begin{array}{l}\text { Multi. } \\
\text { hospital } \\
(n=4)\end{array}$ & $128(137)$ & $50-54^{\mathrm{a} \text { or }} \mathrm{b}$ & Postnatal & $\begin{array}{l}\text { Age } \geq 18 \text { Pregnancy } \\
\text { complicated by } \\
\text { preeclampsia } \\
\text { speaking Dutch }\end{array}$ & - & $\begin{array}{l}\text { Mild preeclampsia: } \\
\text { Severe preeclampsia }\end{array}$ & $\begin{array}{l}\text { Clinical } \\
\text { records }\end{array}$ & $\begin{array}{l}6 \text { wks } 12 \\
\text { wks }\end{array}$ & SRIP & Postal \\
\hline $\begin{array}{l}\text { Lev-Wiesel } \\
\text { et al. } 2009\end{array}$ & Israel & $\begin{array}{l}\text { Pros. } \\
\text { cohort }\end{array}$ & $\begin{array}{l}\text { Single } \\
\text { hospital }\end{array}$ & 1071 & $96^{c \text { ord }}$ & Antenatal & $\begin{array}{l}\text { Women }>=5 \mathrm{mths} \\
\text { pregnant at the } \\
\text { time of recruitment }\end{array}$ & $\begin{array}{l}\text { Women under } \\
\text { psychiatric } \\
\text { treatment }\end{array}$ & $\begin{array}{l}\text { High-risk pregnancy } \\
\text { Delivery } \\
\text { complications (CS, } \\
\text { preterm delivery or } \\
\text { fetal distress etc) }\end{array}$ & $\begin{array}{l}\text { Clinical } \\
\text { records } \\
\text { Self-report }\end{array}$ & $\begin{array}{l}1 \mathrm{mth} \\
6 \mathrm{mths}\end{array}$ & PSS-I & $\begin{array}{l}\text { Interview } \\
\text { (face-to-face/ } \\
\text { telephone) }\end{array}$ \\
\hline \multirow[t]{2}{*}{$\begin{array}{l}\text { Sorenson \& } \\
\text { Tschetter } \\
2010\end{array}$} & US & $\begin{array}{l}\text { Cross- } \\
\text { sectional }\end{array}$ & Commu-nity & 71 & $75^{c}\left(53^{b}\right)$ & Postnatal & $\begin{array}{l}\text { Listed in phone } \\
\text { book Having } \\
\text { 'landline' phone } \\
\text { numbers }\end{array}$ & $\begin{array}{l}\text { All others who did } \\
\text { not meet inclusion } \\
\text { criteria }\end{array}$ & Birth complication: & Not stated & 6-7 mths & PTCS & $\begin{array}{l}\text { Interview } \\
\text { (telephone) }\end{array}$ \\
\hline & Netherlands & & & 175 (137) & $71-91^{c}$ & Antenatal & & & & & & PSS-SR & Interview \\
\hline
\end{tabular}


Table 4 Characteristic of the included studies (Continued)

\begin{tabular}{|c|c|c|c|c|c|c|c|c|c|c|c|c|c|}
\hline $\begin{array}{l}\text { Stramrood } \\
\text { et al. } 2010\end{array}$ & & $\begin{array}{l}\text { Pros. } \\
\text { cohort }\end{array}$ & $\begin{array}{l}\text { Single } \\
\text { hospital \& } \\
\text { single } \\
\text { midwifery } \\
\text { practice }\end{array}$ & & & & $\begin{array}{l}\text { Women hospitalised } \\
\text { with preeclampsia } \\
\text { or PPROM }\end{array}$ & $\begin{array}{l}\text { Critically ill, multiple } \\
\text { pregnancy, A history } \\
\text { of intrauterine fetal } \\
\text { death, Alcohol/drug } \\
\text { dependence Pre- } \\
\text { existing medical } \\
\text { conditions (eg. } \\
\text { diabetes, } \\
\text { hypertension, } \\
\text { cardiovascular, renal } \\
\text { diseases) }\end{array}$ & $\begin{array}{l}\text { Preeclampsia } \\
\text { PPROM }\end{array}$ & $\begin{array}{l}\text { Clinical } \\
\text { records }\end{array}$ & $\begin{array}{l}6 \text { wks } 15 \\
\text { mths }\end{array}$ & & \\
\hline $\begin{array}{l}\text { Stramrood } \\
\text { et al. } 2011\end{array}$ & Netherlands & $\begin{array}{l}\text { Cross- } \\
\text { sectional }\end{array}$ & $\begin{array}{l}\text { Multi. } \\
\text { Hospital } \\
(n=3) \\
\text { Midwifery } \\
\text { practice } \\
(n=4)\end{array}$ & 428 & $47^{\mathrm{a} \text { or } b}$ & Postnatal & $\begin{array}{l}\text { Women delivered } 2 \\
\text { to } 6 \text { months prior } \\
\text { to study with >=16 } \\
\text { weeks of gestation }\end{array}$ & - & $\begin{array}{l}\text { Pregnancy } \\
\text { complications (pre- } \\
\text { eclampsia, HELLP, } \\
\text { antenatal blood loss } \\
\text { or intrauterine } \\
\text { death etc) Delivery } \\
\text { complications (PPH, } \\
\text { manual placenta } \\
\text { removal or ICU etc) }\end{array}$ & Self-report & 2-6 mths & TES-B & Web-based \\
\hline
\end{tabular}

NoteCS: caesarean section; EICS: elective caesarean section; ICU: intensive care units; NICU: neonatal intensive care units; PPROM: preterm premature rupture of membranes; HELLP: HELLP syndrome.

PPH: postpartum haemorrhage.

Pros: prospective; Retro: retrospective; wks: weeks; mths: months; yrs: years.

\# Engelhard (2002) included women's partner in their study sample, but data on women was only extracted.

† Sample size of postnatal women and response rate at postnatal period.

a) The number of all eligible women, of whom those who took part in the study.

b) The number of women who were approached, of whom questionnaire/interview were actually returned or completed.

c) The number of women who agreed to participate after the researcher approached to them, of whom questionnaires/interview were actually returned or completed.

d) Uncertain how the response rate was calculated. 


\section{Methodological quality}

The overall quality of these studies was moderate to low when assessed for the methodological quality using CASP criteria [37]. Generalisability, a lack of clear definitions of maternal morbidity and a possibility of measurement errors of PTSD/PTSD symptoms were the main issues identified from the selected studies. The methodological quality of the selected studies is summarised in Additional file 3 and discussed below. As no comparable studies were identified, and as quantitative data could not be statistically combined for a meta-analysis, extracted data were synthesised into a narrative summary. There was wide clinical heterogeneity, with different outcome measures and timing of assessment used across the included studies.

\section{Representativeness and generalisability}

Study sample sizes ranged from 71 [48] to 1071 women [43]. The majority did not report power analysis except for Stramrood et al. [44], Creedy [41] and Hoedjes et al. [42]. The power calculation cited by Creedy [41] appeared to be performed after study recruitment, but criteria used to inform statistical significance (what difference they expected to see) was not described. Stramrood et al. [44] calculated a sample size to produce $80 \%$ statistical power for $\mathrm{p}=0.01$. The study had two followup time points (6 weeks and 15 months postpartum). There were sufficient cases at the first follow-up point, but substantial loss to follow up in one of the study groups resulted in the sample size being smaller than that calculated for the second follow-up. Hoedjes et al. [42] discussed the possibility of low power to detect clinically meaningful differences in PTSD and related symptoms between their study groups (mild and severe pre-eclamptic women) due to the relatively low numbers of outcomes in their sample.

Response rates varied within and between studies (47\% - 96\%) as did the definition of the response rate. Some studies [47] defined the response rate as the number of women who entered the study from among all women who were eligible, while others defined it as the number of women who took part in the study from among those who were approached or agreed to participate at the researcher's initial approach. In the latter cases, due to the fact that women who refused were excluded from the denominators, high response rates do not necessarily indicate good representativeness of the sample. Possible bias caused by refusal was not discussed or reported in many of the studies.

Adewuya et al. [47] recruited all women eligible (postpartum women who attended postnatal and infant immunisation clinics at 6 weeks at five government health centres in Nigeria), 95\% of whom participated in the study. The study did not have any pre-specified exclusion criteria, but a few women (5\%) who were critically ill, spoke a different language or refused were excluded. The study clearly described the potential bias caused by nonparticipants who were likely to be a high risk group resulting in possible underestimation of PTSD cases.

In a study by Lev-Wiesel et al. [43] a convenience sample of pregnant women were recruited from one hospital in Israel. Women under psychiatric care were excluded. Of the women recruited, $96 \%$ participated in a follow up interview at one and six months postpartum.

In the studies by Hoedjes et al. [42] and Stramrood et al. [49] from the Netherlands, participants were recruited from several centres (hospitals and/or midwifery practices). However, whether these sites were selected purposefully (e.g. geographical convenience) or based on pre-defined criteria was not clearly reported. Hoedjes et al. [42] approached all eligible women (whose pregnancy was complicated by pre-eclampsia), while Stramrood et al. [49] recruited a maximum of 200 women per hospital and 100 per midwifery practice to ensure ratios of delivery places were comparable with those in the Dutch population of childbearing women. Hoedjes et al. [42] clearly discussed the possibility of non-response bias. Non-native Dutch women were under-represented despite ethnicity potentially contributing to PTSD.

Stramrood et al. [44] approached pregnant women hospitalized with pre-eclampsia/HELLP (Hemolysis, Elevated Liver enzyme levels and a Low Platelet count) syndrome or preterm premature rupture of membranes (PPROM) in one university hospital. They also recruited a healthy control group with uneventful pregnancies from an independent midwifery practice. Another two studies included from the Netherlands recruited women who experienced pre-eclampsia and those who did not from one tertiary level hospital [45,46]. It was unclear whether all individuals who were eligible were actually approached or if they used the partial sample (e.g. convenient, matched). Engelhard et al. [46], Baecke et al. [45] and Stramrood et al. [44] excluded multiparous women from their samples.

Cohen et al. [40] included multiple study sites in the Toronto area of Canada but site selection criteria were not clearly reported. They also excluded multiparous women, women who could not be contacted for postpartum interview and women at risk of PTSD due to poor infant outcome (e.g. premature birth, multiple birth, admission to neonatal intensive care). The authors justified these exclusions saying "the mothers' experience with these infants would be highly stressful because of the circumstances related to the infant rather than to the experience of childbirth per se." (p.316). The authors however noted that by excluding these women, who may have been more likely to experience a difficult delivery, the extent of PTSD was probably underestimated in their study. 
Ayers [39] recruited women planning normal labour and birth (ie. not booked for elective caesarean) from one hospital in England. Creedy [41] recruited women in their last trimester of pregnancy from four public hospital antenatal clinics, excluding those at high risk for obstetric problems. Women who had preterm birth or stillbirth were also excluded "due to the high probability of psychiatric morbidity following such event" (p.83). The findings from these studies are less likely to be generalisable to women with high medical risks because poor infant outcomes or elective caesarean section can be a consequence of a maternal complication.

A study from the United States [48] approached women who advertised their birth announcements in a local newspaper during a specified time period (59 days), and who had listed landline phone numbers in a publicly available phone number book. Although almost all women who gave birth at this time put their birth announcements in the newspaper (99\%), the proportion of women who listed phone numbers was unclear. Many of the women $(47 \%)$ contacted did not agree to participate or did not return the questionnaire.

In summary, due to a lack of clarity of reporting, assessing sample representativeness was not possible in many studies. Most studies had relatively small sample sizes and/or excluded a particular sub-group of women which could affect the generalisability of their findings.

\section{Exposure to maternal morbidity}

In four studies, the main exposure variable was preeclampsia [42,44-46]. Baecke et al. [45] and Stramrood et al. [44] defined pre-eclampsia as "blood pressure exceeding 140/90 $\mathrm{mmHg}$ and proteinuria as urinary protein excretion over $300 \mathrm{mg}$ per $24 \mathrm{~h}$ ". The same criteria were used by Engelhard et al., but in addition, they required clinical management of pre-eclampsia for at least one week. In the study by Hoedjes et al. [42], the criteria adopted by Baecke et al. [45] and Stramrood et al. [44] was used to distinguish mild from severe pre-eclampsia ${ }^{\mathrm{a}}$ [50]. Baecke et al. [45] and Engelhard et al. [46] did not include a separate variable for severe pre-eclampsia, but pre-eclampsia was divided into two groups, preterm pre-eclampsia and term pre-eclampsia which were used as a proxy of severity of the condition. Engelhard et al. [46] also used gestational age at admission to hospital, caesarean section and length of hospital stay as indicators of severity.

The exposure variable in the study by Cohen et al. [40] was a 'difficult' birth which included maternal complications (e.g., heavy bleeding after birth, uterine infection), unplanned pregnancy, perineal trauma, long labour (12 or more hours), induced labour, assisted or caesarean birth and severe labour pain. The definition of each complication was not reported.
The remaining six studies [39,41,43,47-49] assessed potential predictors of PTSD or PTSD symptoms following childbirth with no specific exposure of interest, but included variables related to maternal morbidity. Adewuya et al. [47] included hospital admission during pregnancy and manual removal of placenta. Reasons for hospital admission were not presented, but authors noted that "late detection of serious and life-threatening health problems in pregnancy could necessitate hospital admission" (p.287).

Ayers [39] included data on delivery complications and the amount of blood loss but did not state if this was estimated or measured. The type of bleeding (eg. vaginal, postpartum haemorrhage) was also uncertain. Data about other obstetric events such as infant complications, mode of birth, length of labour and use of analgesia were obtained from clinical records. However, the definition of each condition in the category of delivery complication was not given. With a high proportion of women categorised as having a delivery complication (20\%), it is likely that some cases might not meet the definition of severe maternal morbidity.

Creedy [41] asked women over the telephone at 4 to 6 weeks postpartum if they experienced any maternal complications following birth (the time frame for onset was not reported). Self-reported responses included postpartum haemorrhage, medical condition (e.g. anaemia), infection (infection site not mentioned), and severe post-delivery pain. Accuracy of women's retrospective self-report of obstetric events was checked through chart audit with a random selection of participants from one site out of four $(6 \%, n=30)$ which showed the overall agreement rate was 95\% [51]. Information on the item-specific accuracy was not provided. Again, considering high overall rates of self-reported maternal complications (more than 14\%) among the low obstetric risk group, the majority of cases may not have been severe or life-threatening.

Stramrood et al. [49] collected information from participants using a web-based questionnaire, on pregnancy complications (e.g. pre-eclampsia/HELLP, antenatal blood loss, intrauterine death) and labour and birth complications (e.g. postpartum haemorrhage, manual placenta removal, ICU admittance).

Lev-Wiesel et al. [43] included high-risk pregnancy 'defined as such by their gynaecologists'. The study also collected self-reported delivery complications at approximately 1 month after childbirth that included caesarean section, preterm labour, premature delivery and fetal distress. Sorenson and Tschetter [48] also included a variable of maternal birth complications, but the definition, type of complication and data source were not described.

In summary, apart from studies that primarily aimed to assess the effects of a specific type of maternal morbidity, the definition and type of maternal complication were often poorly described. Mild and more severe cases 
of maternal morbidity were likely to be combined. Moreover, obstetric procedures and maternal and fetal conditions tended to be pooled. Maternal morbidity in the selected studies does not necessarily comply with severe maternal morbidity as described earlier $[18,27]$.

\section{Measures of PTSD}

Measures of PTSD or PTSD symptoms varied. In Adewuya et al. [47], PTSD was assessed by a psychiatrist and a trained clinician using the MINI International Neuropsychiatric Interview (M.I.N.I) - a clinician administered, short structured diagnostic interview for DSM-IV and ICD-10 psychiatric disorders [52]. Creedy [41] used the PTSD Symptom Scale - Interview version (PSS-I), which supports structured clinical interview to facilitate the diagnosis of PTSD [53]. The other studies used selfreport scales including the PTSD Symptom Scale - Selfreport (PSS-SR) [53], the Davidson Trauma Scale (DTS) [54], the Self-rating Inventory for PTSD (SRIP) [55,56], the Traumatic Event Scale-B (TES-B) [57], the Impact of Event Scale (IES) [58] and the post-traumatic childbirth stress inventory (PTCS) [59]. Whilst the first four PTSD scales (PSS, DTS, SRIP and TES-B) follow DSM symptom criteria, the IES has less useful PTSD diagnostic utility, as it does not measure hyper-arousal, one of three dimensions of PTSD symptoms, but does provide a good indicator of PTSD [60] and is one of the most widely used screening measures for PTSD. Most scales (PSS, DTS, SRIP, IES) showed strong validity against clinical interviews following a variety of trauma events. The
TES-B has been developed specifically for PTSD following childbirth and includes all DSM-IV criteria for PTSD. However, it has not yet been validated with clinical interviews [61].

Two studies $[39,41]$ used both the PSS (either selfreport or interview version) and the IES; the PSS for estimating the incidence/prevalence of PTSD following childbirth and the IES for examining predictors of PTSD symptoms. The PSS and the IES were the most frequently used scales in the current review, but as scoring systems used in each study were different, results are not comparable. The scoring methods for DTS, PSS and SRIP adopted by Cohen et al. [40], Engelhard et al. [46] and Hoedjes et al. [42] respectively were also slightly modified by researchers from the original scoring methods in order to meet DSM-IV criteria. Table 5 provides a general description of each self-report instrument and indication of the size of measurement error and likely impact on the study results.

In summary, the PSS and the DTS have high specificity (that is, the proportion of individuals classified as negative by diagnostic interview, who are correctly identified by the self-rated scale: true negative) and relatively low sensitivity (proportion of individuals classified as positives by diagnostic interview, who are correctly identified by the self-report scale: true positive). Potential measurement errors could underestimate true PTSD cases. On the other hand, the IES and the SRIP are highly sensitive and probably recognise almost all true PTSD cases [62]. However, due to relatively low

Table 5 Summary of advantages and potential measurement errors of selected self-report instrument of PTSD symptoms

\begin{tabular}{|c|c|c|c|c|c|c|}
\hline Tool & DTS & IES & PSS-SR & PTCS & SRIP & TES-B \\
\hline No. of items & 17 & 15 & 17 & 15 & 22 & 17 \\
\hline Response scale & 5 point Likert & 4 point Likert & 4-point Likert & 5-point Likert & 4 point Likert & 4 point Likert \\
\hline $\begin{array}{l}\text { Validity } \\
\text { - Sensitivity } \\
\text { - Specificity }\end{array}$ & $\begin{array}{l}0.69 \\
0.95 \\
\text { (cut-off of } 40 \\
\text { on sum score) }\end{array}$ & $\begin{array}{l}1.00 \\
0.78 \\
\text { (cut-off of } 19 \\
\text { on sum score) }\end{array}$ & $\begin{array}{l}0.62 \\
1.00\end{array}$ & $\begin{array}{l}\text { Not yet } \\
\text { established }\end{array}$ & $\begin{array}{l}0.86 \\
0.71\end{array}$ & $\begin{array}{l}\text { Not yet } \\
\text { established }\end{array}$ \\
\hline $\begin{array}{l}\text { Reliability } \\
\text { - Internal consistency }\end{array}$ & 0.99 & $\begin{array}{l}0.78 \text { (intrusions) } \\
0.82 \text { (avoidance) }\end{array}$ & 0.91 & 0.93 & $0.90-0.94$ & 0.84 \\
\hline - Test-retest & 0.86 & $\begin{array}{l}0.89 \text { (intrusions) } \\
0.79 \text { (avoidance) }\end{array}$ & 0.74 & - & $0.60-0.97$ & - \\
\hline Reporting period & Past week & Past week & $\begin{array}{l}\text { Past two } \\
\text { weeks }\end{array}$ & Not available & $\begin{array}{l}\text { Past four } \\
\text { weeks }\end{array}$ & $\begin{array}{l}\text { Past four } \\
\text { weeks }\end{array}$ \\
\hline $\begin{array}{l}\text { Specify stressor of } \\
\text { interest }\end{array}$ & Yes & Yes & Yes & Not available & No & Yes \\
\hline DSM-IV criteria & $B, C, D$ & $B, C$ & $B, C, D$ & Not available & $B, C, D$ & $A, B, C, D, E, F$ \\
\hline
\end{tabular}

Note: DSM-IV criteria: $\mathrm{A}=$ Stressor, $\mathrm{B}=$ Intrusion/re-experience, $\mathrm{C}=$ Avoidance/numbing, $\mathrm{D}=$ Hyperarousal, $\mathrm{E}=\mathrm{Duration}, \mathrm{F}=\mathrm{Disability}$. Validity and reliability were obtained from Foa et al. [53] for the PSS-SR; Davidson et al. [54] for the DTS; and Horowitz et al. [58] and Wohlfarth et al. [62] for the IES and Stramrood et al. [61] for TES-B. *The original study to test the PTCS [59] was unpublished and unobtainable. 
specificity, potential measurement errors could lead to overestimation of the true cases, although this will depend on the cut-off used to define the cases.

As Olde et al. [4] described, the term to describe PTSD related outcomes need to be clarified as different tools measure different aspects of PTSD. From this point in the current review, the term PTSD will only be used when all diagnostic criteria of the DSM-IV-R (A: stressor; B: intrusion; C: avoidance; D: hyperarousal; E: duration and F: Disability) were met. For cases in which all symptom criteria (B, C and D) [1] were met, but some other criteria (either $\mathrm{A}, \mathrm{E}$ or F) were missing, the term PTSD-profile will be used. The term PTSD symptom(s) will be used when only partial symptom criteria were met or to indicate each symptom; intrusion; avoidance or hyperarousal.

Is there difference in prevalence/incidence of PTSD (profile/symptoms) between women who experienced severe maternal morbidity and those who did not? Five studies $[40,42,44-46]$ provided information on differences in the prevalence of PTSD profile or PTSD symptoms according to maternal morbidity status (Table 6).
Hoedjes et al. [42] examined the prevalence of PTSD profile at 6 and 12 weeks postpartum among women who experienced mild $(n=35)$ or severe pre-eclampsia $(n=114)$. On average, the prevalence of PTSD profile (measured with the SRIP) at 6 weeks postpartum $(n=128)$ was $9 \%$ for women who experienced either mild or severe preeclampsia, but the prevalence was higher for women who experienced severe pre-eclampsia (11\%) than those who experienced mild pre-eclampsia (3\%). At 12 weeks postpartum $(n=137)$, the overall prevalence of PTSD profile was $5 \%$, the prevalence for women with severe preeclampsia still higher (7\%), compared with women with mild pre-eclampsia (0\%). Hoedjes et al. [42] also examined differences in the prevalence of each PTSD symptom (intrusion, avoidance and hyperarousal) between women with mild pre-eclampsia and severe pre-eclampsia. The prevalence of each symptom was higher for women with severe pre-eclampsia than women with mild preeclampsia at 6 and 12 weeks postpartum.

Engelhard et al. [46] compared the prevalence of PTSD profile in two small groups of women who experienced preterm pre-eclampsia $(n=18)$ and term pre-eclampsia $(n=23)$,

Table 6 Difference in prevalence of PTSD profile/symptom (women with complication vs. women without)

\begin{tabular}{|c|c|c|c|c|c|}
\hline \multirow[t]{2}{*}{ Study } & \multirow[t]{2}{*}{$\mathrm{N}^{*}$} & \multirow[t]{2}{*}{ Instrument } & \multirow[t]{2}{*}{ Time of Assessment } & \multicolumn{2}{|l|}{ PTSD profile \& symptoms (\%) } \\
\hline & & & & Women with complication & Women without (less) complication \\
\hline \multirow[t]{3}{*}{ Baecke et al. 2009} & 169 & IES & $6-18$ mths & PTSD symptoms & \\
\hline & & & & 44\%: Preterm preeclampsia & 41\%: Preterm, no complication \\
\hline & & & & 11\%: Term preeclampsia & 11\%: Term, uneventful \\
\hline \multirow[t]{4}{*}{ Cohen et al. 2004} & 198 & DTS & $8-10$ wks & PTSD profile & \\
\hline & & & & 0\%: Maternal complication (2+) & 0\%: Maternal complication (0-1) \\
\hline & & & & PTS & \\
\hline & & & & 59\%: Maternal complication (2+) & 30\%: Maternal complication (0-1) \\
\hline \multirow[t]{3}{*}{ Engelhard et al. 2002} & 113 & PSS-SR & Within 2 yrs & PTSD profile & \\
\hline & & & & 28\%: Preterm preeclampsia & 28\%: Preterm, no complication \\
\hline & & & & 17\%: Term preeclampsia & 0\%: Term, uneventful \\
\hline \multirow[t]{8}{*}{ Hoedjes et al. 2011} & 128 & SRIP & 6 wks & PTSD profile & N/A \\
\hline & & & & 9\%: severe \& mild preeclampsia & \\
\hline & & & & 11\%: severe preeclampsia & \\
\hline & & & & 3\%: mild preeclampsia & \\
\hline & 137 & & 12 wks & PTSD profile & \\
\hline & & & & 5\%: severe \& mild preeclampsia & \\
\hline & & & & 7\%: severe preeclampsia & \\
\hline & & & & 0\%: mild preeclampsia & \\
\hline \multirow[t]{6}{*}{ Stramrood et al. 2010a } & 163 & PSS-SR & 6 wks & PTSD profile & \\
\hline & & & & 11\%: Preeclampsia & 3\% Term, uneventful \\
\hline & & & & 17\%: PPROM & \\
\hline & 137 & & 15 mths & PTSD profile & \\
\hline & & & & 11\%: Preeclampsia & 0\% Term, uneventful \\
\hline & & & & 3\%: PPROM & \\
\hline
\end{tabular}


Table 7 Association and effect size of maternal morbidity and other variables on PTSD (profile/symptoms)

\begin{tabular}{|c|c|c|c|c|c|c|c|c|}
\hline \multirow{2}{*}{$\frac{\text { Study }}{\text { Adewuya et al., } 2006}$} & \multirow{2}{*}{$\frac{\mathbf{N}}{876}$} & \multicolumn{4}{|l|}{ Method } & \multicolumn{3}{|c|}{ Results (in case of ORs: risk vs. reference) } \\
\hline & & \multirow[t]{7}{*}{$\begin{array}{l}\text { Stepwise } \\
\text { multiple } \\
\text { regressions }\end{array}$} & \multirow[t]{7}{*}{ M.I.N.I } & \multirow[t]{7}{*}{ PTSD } & \multirow[t]{7}{*}{6 wks } & $\begin{array}{l}\text { Admission due to } \\
\text { pregnancy complication: } \\
\text { yes vs. no }\end{array}$ & Adjusted OR: $11.9^{\dagger}$ & (95\%Cl: 6.4-22.1) \\
\hline & & & & & & Mode of delivery & & \\
\hline & & & & & & $\begin{array}{l}\text { - Instrumental vs. } \\
\text { spontaneous vaginal }\end{array}$ & Adjusted OR: $7.9^{\dagger}$ & (95\%Cl: $3.9-16.2)$ \\
\hline & & & & & & $\begin{array}{l}\text { - EmCS vs. spontaneous } \\
\text { vaginal }\end{array}$ & Adjusted OR: $7.3^{\dagger}$ & $(95 \% \mathrm{Cl}: 3.5-15.2)$ \\
\hline & & & & & & $\begin{array}{l}\text { - EICS vs. spontaneous } \\
\text { vaginal }\end{array}$ & Adjusted OR: 2.0 & (95\%Cl: 0.4-8.9) \\
\hline & & & & & & $\begin{array}{l}\text { Mode of placental } \\
\text { removal: manual } \\
\text { vs. normal }\end{array}$ & Adjusted OR: $5.0^{\dagger}$ & (95\%Cl: $2.4-10.1)$ \\
\hline & & & & & & $\begin{array}{l}\text { Perceived control } \\
\text { in childbirth: } \\
\text { LAS < } 40 \text { vs. }>40\end{array}$ & Adjusted OR: $5.1^{\dagger}$ & (95\%Cl: 2.7-9.5) \\
\hline \multirow[t]{13}{*}{ Ayers, 1999} & 220 & \multirow[t]{2}{*}{$\begin{array}{l}\text { Mann Whitney } \\
\text { Spearman's } \\
\text { correlation }\end{array}$} & \multirow[t]{13}{*}{ IES } & \multirow[t]{10}{*}{$\begin{array}{l}\text { Intrusions } \\
\text { (sub-sum score) }\end{array}$} & \multirow[t]{5}{*}{6 wks } & $\begin{array}{l}\text { Delivery complication: } \\
\text { presence vs. absence }\end{array}$ & ns & \\
\hline & & & & & & Amount of blood loss & ns & \\
\hline & & Kruskal-Wallis & & & & Type of delivery (eg. EmCS) & ns & \\
\hline & & \multirow{7}{*}{$\begin{array}{l}\text { Partial correlation } \\
\text { (removing an effect } \\
\text { of PTSD symptoms } \\
\text { in pregnancy) }\end{array}$} & & & & $\begin{array}{l}\text { Appraising birth } \\
\text { as traumatic }\end{array}$ & $\begin{array}{l}\text { Partial correlation } \\
\beta=.20 * * \text { (one tailed) }\end{array}$ & \\
\hline & & & & & & $\begin{array}{l}\text { Different from } \\
\text { how women } \\
\text { wanted to be }\end{array}$ & Partial correlation $\beta=.17^{*}$ & \\
\hline & 201 & & & & \multirow[t]{5}{*}{6 mths } & $\begin{array}{l}\text { Delivery complication: } \\
\text { presence vs. absence }\end{array}$ & ns & \\
\hline & & & & & & Amount of blood loss & ns & \\
\hline & & & & & & $\begin{array}{l}\text { Type of delivery } \\
\text { (eg. EmCS) }\end{array}$ & ns & \\
\hline & & & & & & $\begin{array}{l}\text { Appraising birth } \\
\text { as traumatic }\end{array}$ & $\begin{array}{l}\text { Partial correlation } \\
\beta=.19 * * \text { (one tailed) }\end{array}$ & \\
\hline & & & & & & $\begin{array}{l}\text { Different from } \\
\text { how women } \\
\text { wanted to be }\end{array}$ & $\begin{array}{l}\text { Partial correlation } \\
\beta=.22^{* *}\end{array}$ & \\
\hline & 220 & & & \multirow[t]{3}{*}{$\begin{array}{l}\text { Avoidance } \\
\text { (sub-sum score) }\end{array}$} & \multirow[t]{3}{*}{6 wks } & $\begin{array}{l}\text { Delivery complication: } \\
\text { presence vs. absence }\end{array}$ & ns & \\
\hline & & & & & & Amount of blood loss & ns & \\
\hline & & & & & & $\begin{array}{l}\text { Type of delivery } \\
\text { (eg. EmCS) }\end{array}$ & ns & \\
\hline
\end{tabular}


Table 7 Association and effect size of maternal morbidity and other variables on PTSD (profile/symptoms) (Continued)

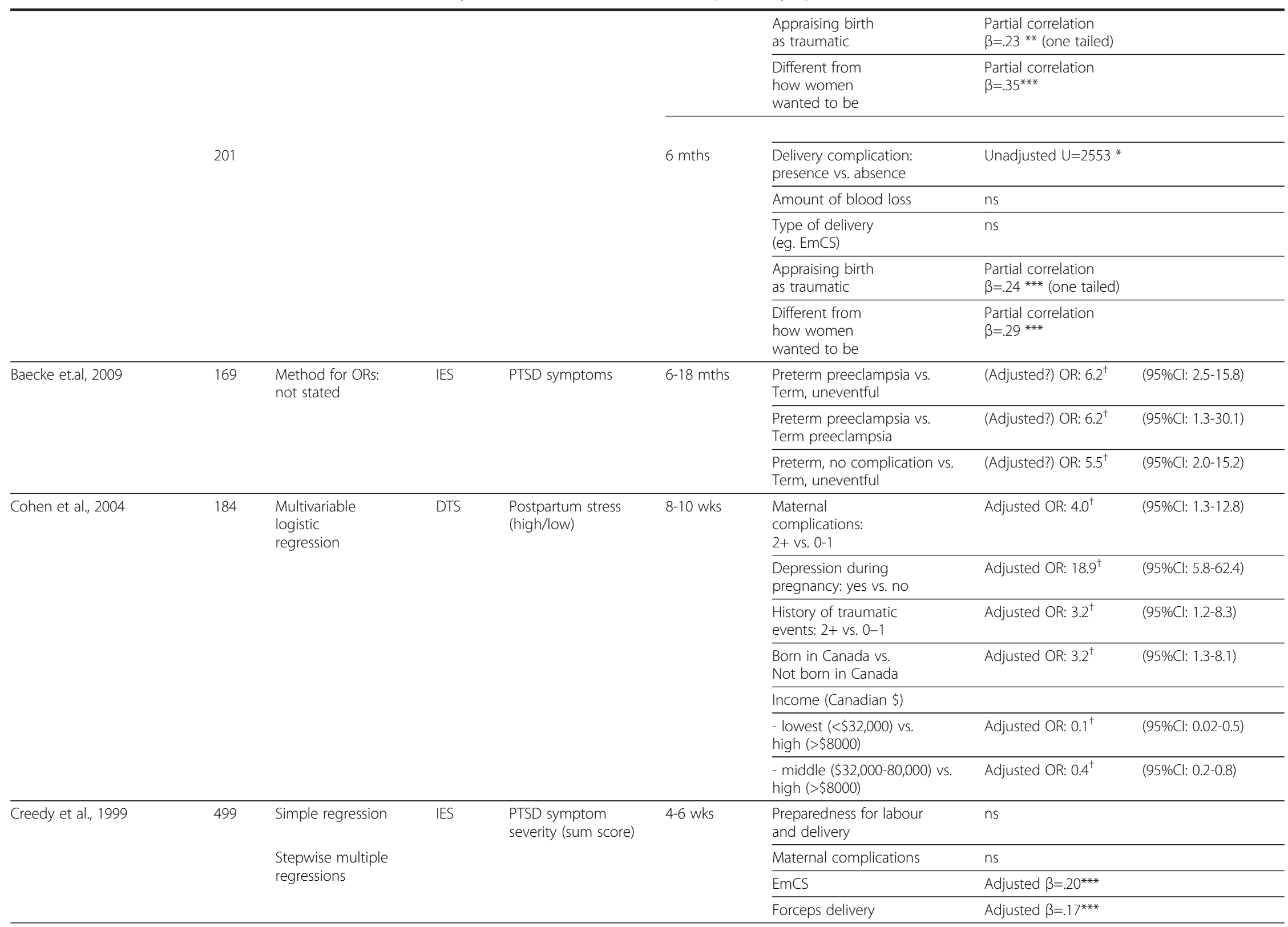


Table 7 Association and effect size of maternal morbidity and other variables on PTSD (profile/symptoms) (Continued)

\begin{tabular}{|c|c|c|c|c|c|c|c|c|}
\hline & & & & & & Vacuum delivery & Adjusted $\beta=.14^{* *}$ & \\
\hline & & & & & & Post-delivery pain & Adjusted $\beta=.16^{* * *}$ & \\
\hline & & & & & & Neonatal complications & Adjusted $\beta=.10^{*}$ & \\
\hline & \multirow{7}{*}{141} & \multirow[t]{3}{*}{$\begin{array}{l}\text { Hierarchical multiple } \\
\text { regression }\end{array}$} & & & & $\begin{array}{l}\text { Final model (Accounted } \\
\text { for } 21 \% \text { of variance) } \\
\end{array}$ & & \\
\hline & & & & & & $\begin{array}{l}\text { Perception of maternity } \\
\text { care (step 1) }\end{array}$ & Adjusted $\beta=.32^{* * *}$ & \\
\hline & & & & & & $\begin{array}{l}\text { Obstetric intervention } \\
\text { (step 2) }\end{array}$ & Adjusted $\beta=.26^{* * *}$ & \\
\hline & & \multirow[t]{4}{*}{$\begin{array}{l}\text { Multiple } \\
\text { regression }\end{array}$} & & & 3 mths & $\frac{\frac{\text { Final model }}{\text { (Accounted for }}}{24 \% \text { variance) }}$ & & \\
\hline & & & & & & $\begin{array}{l}\text { Preparedness for } \\
\text { labour and delivery }\end{array}$ & Adjusted $\beta=-16^{*}$ & \\
\hline & & & & & & Obstetric intervention & Adjusted $\beta=.15^{*}$ & \\
\hline & & & & & & $\begin{array}{l}\text { Perception of maternity } \\
\text { care }\end{array}$ & Adjusted $\beta=.42^{* * *}$ & \\
\hline \multirow[t]{6}{*}{ Engelhard et.al, 2002} & \multirow[t]{6}{*}{113} & \multirow{6}{*}{$\begin{array}{l}\text { Hierarchical } \\
\text { multiple } \\
\text { regression }\end{array}$} & \multirow[t]{6}{*}{ PSS-SR } & \multirow[t]{6}{*}{$\begin{array}{l}\text { PTSD symptom } \\
\text { severity }\end{array}$} & \multirow[t]{6}{*}{ Within 2 yrs } & $\frac{\text { Final mode (Accounted }}{\text { for } 61 \% \text { of the variance) }}$ & & \\
\hline & & & & & & $\begin{array}{l}\text { Gestational age at } \\
\text { admission (step 1) }\end{array}$ & ns & \\
\hline & & & & & & $\begin{array}{l}\text { Peritraumatic distress } \\
\text { (step 2) }\end{array}$ & ns & \\
\hline & & & & & & $\begin{array}{l}\text { Peritraumatic dissociation } \\
\text { (step 2) }\end{array}$ & Adjusted $\beta=.27^{* *}$ & \\
\hline & & & & & & $\begin{array}{l}\text { Negative interpretations } \\
\text { (step 3) }\end{array}$ & Adjusted $\beta=-.40^{*}$ & \\
\hline & & & & & & $\begin{array}{l}\text { Thought suppression } \\
\text { (step 3) }\end{array}$ & Adjusted $\beta=-.25^{*}$ & \\
\hline \multirow[t]{5}{*}{ Hoedjes et al., 2011} & \multirow[t]{5}{*}{149} & \multirow{5}{*}{$\begin{array}{l}\text { Logistic regression } \\
\text { for each variable } \\
\text { (adjusting only for } \\
\text { assessment time - } \\
6 \text { and } 12 \text { weeks } \\
\text { postpartum using } \\
\mathrm{GEE}^{\ddagger} \text { ) }\end{array}$} & \multirow[t]{5}{*}{ SRIP } & \multirow[t]{4}{*}{$\begin{array}{l}\text { PTSD profile } \\
\text { (yes/no) }\end{array}$} & \multirow[t]{4}{*}{$6-12$ wks } & $\begin{array}{l}\text { Severity of preeclampsia: } \\
\text { severe vs. mild }\end{array}$ & Unadjusted OR: 5.0* & (95\%Cl: 0.6-38.8) \\
\hline & & & & & & $\begin{array}{l}\text { Mode of delivery: CS } \\
\text { vs. vaginal }\end{array}$ & Unadjusted OR: $8.4^{*}$ & (95\%Cl: 1.1-65.5) \\
\hline & & & & & & Age & Unadjusted OR: $0.6^{*}$ & (95\%Cl: 0.4-0.7) \\
\hline & & & & & & $\begin{array}{l}\text { Gestational age at } \\
\text { delivery }\end{array}$ & Unadjusted OR: $0.8^{*}$ & (95\%Cl: 0.7-1.0) \\
\hline & & & & $\begin{array}{l}\text { Intrusions } \\
\text { (yes/no) }\end{array}$ & & $\begin{array}{l}\text { Severity of preeclampsia: } \\
\text { severe vs. mild }\end{array}$ & Unadjusted OR: 5.5* & (95\%Cl: 1.6-18.7) \\
\hline
\end{tabular}


Table 7 Association and effect size of maternal morbidity and other variables on PTSD (profile/symptoms) (Continued)

\begin{tabular}{|c|c|c|c|c|c|c|c|c|}
\hline & & & & & & $\begin{array}{l}\text { Mode of delivery: CS } \\
\text { vs. vaginal }\end{array}$ & Unadjusted OR: 4.3* & (95\%Cl: 1.7-10.6) \\
\hline & & & & & & $\begin{array}{l}\text { Admission to NICU: } \\
\text { yes vs. no }\end{array}$ & Unadjusted OR: 5.9* & (95\%Cl: 2.4-15.0) \\
\hline & & & & & & $\begin{array}{l}\text { Perinatal death: } \\
\text { yes vs. no }\end{array}$ & Unadjusted OR: 7.1* & (95\%Cl: 1.8-27.8) \\
\hline & & & & & & Age & Unadjusted OR: $0.8^{*}$ & (95\%Cl: $0.7-0.9)$ \\
\hline & & & & & & $\begin{array}{l}\text { Gestational age at } \\
\text { delivery }\end{array}$ & Unadjusted OR: 0.9* & (95\%Cl: 0.8-0.9) \\
\hline & & & & & & Birth weight & Unadjusted OR: $0.5^{*}$ & (95\%Cl: 0.3-0.8) \\
\hline & & & & Avoidance (yes/no) & & $\begin{array}{l}\text { Mode of delivery: CS } \\
\text { vs. vaginal }\end{array}$ & Unadjusted OR: 3.9* & (95\%Cl: 1.1-13.9) \\
\hline & & & & & & $\begin{array}{l}\text { Admission to NICU: } \\
\text { yes vs. no }\end{array}$ & Unadjusted OR: 4.3* & (95\%Cl: 1.2-15.6) \\
\hline & & & & & & Age & Unadjusted OR: $0.7^{*}$ & (95\%Cl: 0.6-0.8) \\
\hline & & & & & & $\begin{array}{l}\text { Gestational age } \\
\text { at delivery }\end{array}$ & Unadjusted OR: 0.9* & (95\%Cl: 0.8-0.9) \\
\hline & & & & & & Birth weight & Unadjusted OR: $0.4^{*}$ & (95\%Cl: 0.2-1.0) \\
\hline & & & & $\begin{array}{l}\text { Hyperarousal } \\
\text { (yes/no) }\end{array}$ & & $\begin{array}{l}\text { Severity of preeclampsia: } \\
\text { severe vs. mild }\end{array}$ & Unadjusted OR: 3.0* & (95\%Cl: 1.2-7.9) \\
\hline & & & & & & $\begin{array}{l}\text { Mode of delivery: CS } \\
\text { vs. vaginal }\end{array}$ & Unadjusted OR: $2.6^{*}$ & (95\%Cl: 1.2-5.7) \\
\hline & & & & & & $\begin{array}{l}\text { Admission to NICU: } \\
\text { yes vs. no }\end{array}$ & Unadjusted OR: $2.8^{*}$ & (95\%Cl: 1.3-5.8) \\
\hline & & & & & & $\begin{array}{l}\text { Perinatal death: } \\
\text { yes vs. no }\end{array}$ & Unadjusted OR: $6.6^{*}$ & (95\%Cl: 1.1-39.6) \\
\hline & & & & & & Age & Unadjusted OR: $0.9^{*}$ & (95\%Cl: 0.8-1.0) \\
\hline & & & & & & $\begin{array}{l}\text { Gestational age } \\
\text { at delivery }\end{array}$ & Unadjusted OR: 0.9* & (95\%Cl: 0.8-1.0) \\
\hline & & & & & & Birth weight & Unadjusted OR: $0.6^{*}$ & (95\%Cl: 0.4-0.8) \\
\hline \multirow[t]{5}{*}{ Lev-Wiesel et al, 2009} & 1071 & $\begin{array}{l}\text { Linear multiple } \\
\text { regression }\end{array}$ & PSS-I & $\begin{array}{l}\text { PTSD symptoms } \\
\text { severity }\end{array}$ & 6 mths & $\frac{\text { Final model (Accounted }}{\text { for } 41 \% \text { of the variance) }}$ & & \\
\hline & & & & (sum score) & & $\begin{array}{l}\text { Subjective pain } \\
\text { and distress } \\
\text { during delivery }\end{array}$ & Adjusted $\beta=.51^{* * *}$ & \\
\hline & & & & & & PTS during pregnancy & Adjusted $\beta=.04$ & \\
\hline & & & & & & Delivery complications & Adjusted $\beta=.04$ & \\
\hline & & & & & & $\begin{array}{l}\text { Depression during } \\
\text { pregnancy }\end{array}$ & Adjusted $\beta=.15^{* * *}$ & \\
\hline
\end{tabular}


Table 7 Association and effect size of maternal morbidity and other variables on PTSD (profile/symptoms) (Continued)

\begin{tabular}{|c|c|c|c|c|c|c|c|}
\hline & & & & & & $\begin{array}{l}\text { History of traumatic } \\
\text { events }\end{array}$ & Adjusted $\beta=.08^{* *}$ \\
\hline & & & & & & High risk pregnancy & Adjusted $\beta=.03$ \\
\hline \multirow[t]{2}{*}{ Sorenson \& Tschetter, 2010} & 71 & $\begin{array}{l}\text { Point-biserial } \\
\text { correlation } \\
\text { coefficient }\end{array}$ & PTCS & $\begin{array}{l}\text { Posttraumatic } \\
\text { childbirth stress } \\
\text { (low/high) }\end{array}$ & $6-7$ mths & $\begin{array}{l}\text { Maternal complications: } \\
\text { yes vs. no }\end{array}$ & $\begin{array}{l}\text { Unadjusted } \\
\text { rpbs }=0.28^{+}\end{array}$ \\
\hline & & & & & & $\begin{array}{l}\text { Infant complications: } \\
\text { yes vs. no }\end{array}$ & $\begin{array}{l}\text { Unadjusted } \\
\text { rpbs }=0.25^{\dagger}\end{array}$ \\
\hline \multirow[t]{8}{*}{ Stramrood et al, 2010} & 175 & $\begin{array}{l}\text { Hierarchical } \\
\text { multiple }\end{array}$ & PSS-SR & $\begin{array}{l}\text { PTSD symptoms } \\
\text { severity }\end{array}$ & 6 wks & $\begin{array}{l}\text { Final model (Accounted } \\
\text { for 39\% of the variance) } \\
\end{array}$ & \\
\hline & & & & & & $\begin{array}{l}\text { A history of depression } \\
\text { (step 1) }\end{array}$ & Adjusted $\beta=.23^{* *}$ \\
\hline & & & & & & $\begin{array}{l}\text { BDI scores during } \\
\text { pregnancy (step 1) }\end{array}$ & Adjusted $\beta=.33^{* * *}$ \\
\hline & & & & & & $\begin{array}{l}\text { Death of infant } \\
\text { (step 2) }\end{array}$ & Adjusted $\beta=.29^{* * *}$ \\
\hline & & & & & & $\begin{array}{l}\text { Hospital admission } \\
\text { of the infant (step 2) }\end{array}$ & ns \\
\hline & & & & & & Birth weight (step 2) & ns \\
\hline & & & & & & $\begin{array}{l}\text { Diagnosis of the mother } \\
\text { (PE vs PPROM) (step 2) }\end{array}$ & ns \\
\hline & & & & & & CS (step 2) & ns \\
\hline \multirow[t]{10}{*}{ Stramrood et al, 2011} & 428 & $\begin{array}{l}\text { Hierarchical } \\
\text { multiple } \\
\text { regression }\end{array}$ & TES-B & $\begin{array}{l}\text { PTSD symptoms } \\
\text { severity (sum score) }\end{array}$ & $\begin{array}{l}2 \text { to } \\
6 \text { mths }\end{array}$ & $\frac{\text { Final model (Accounted }}{\text { for } 41 \% \text { of the variance) }}$ & \\
\hline & & & & & & Country of origin (step 1) & Adjusted $\beta=.004$ \\
\hline & & & & & & Primiparity (step 1) & Adjusted $\beta=.06$ \\
\hline & & & & & & $\begin{array}{l}\text { Preeclampsia/HELLP } \\
\text { syndrome (step 1) }\end{array}$ & Adjusted $\beta=.08$ \\
\hline & & & & & & Hypertension (step 1) & Adjusted $\beta=.04$ \\
\hline & & & & & & $\begin{array}{l}\text { Preterm delivery } \\
\text { (step 1) }\end{array}$ & Adjusted $\beta=.04$ \\
\hline & & & & & & $\begin{array}{l}\text { Secondary/tertiary } \\
\text { care (step 2) }\end{array}$ & Adjusted $\beta=-.09$ \\
\hline & & & & & & $\begin{array}{l}\text { Hospital delivery } \\
\text { (step 2) }\end{array}$ & Adjusted $\beta=-.05$ \\
\hline & & & & & & $\begin{array}{l}\text { Induction of labour } \\
\text { (step 2) }\end{array}$ & Adjusted $\beta=-.02$ \\
\hline & & & & & & $\begin{array}{l}\text { Instrumental vaginal } \\
\text { delivery (step 2) }\end{array}$ & Adjusted $\beta=-.08$ \\
\hline
\end{tabular}




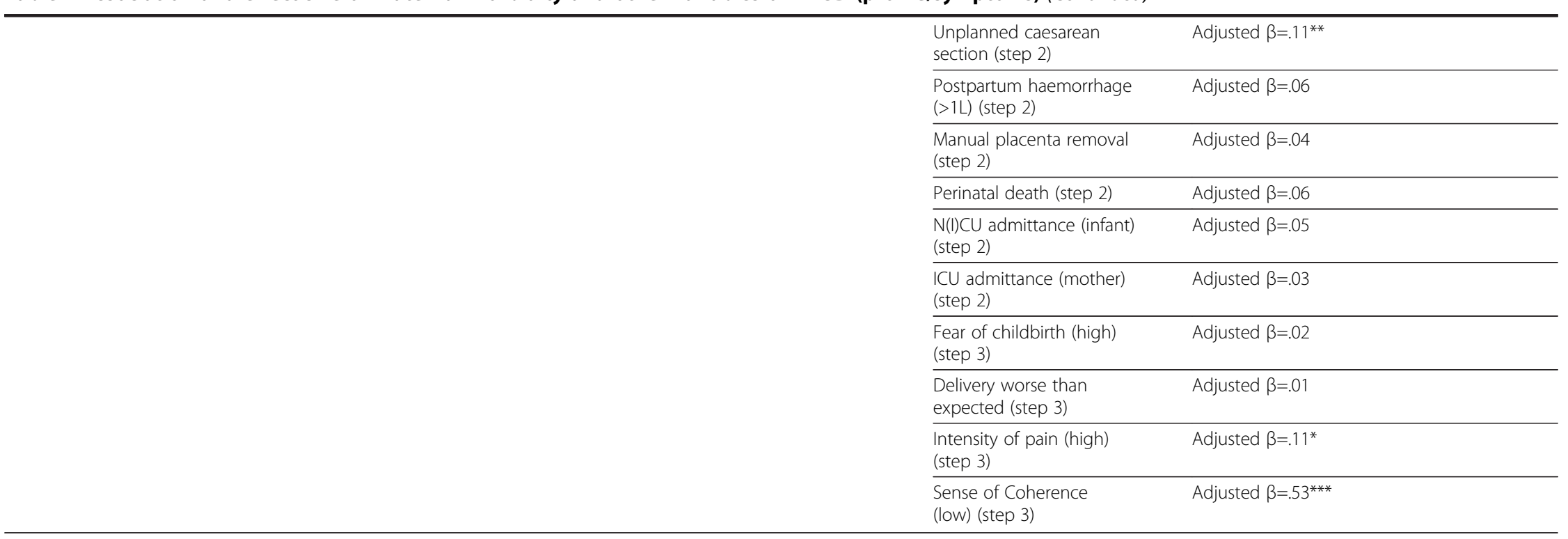

${ }^{*} \mathrm{p}<0.05 .{ }^{* *} \mathrm{p}<0.01,{ }^{* * *} \mathrm{p}<0.001$, ns: none significance, + significance but the level of significance was not reported. ₹ GEE: generalized estimating equation. 
with two "control" groups, matched for gestational age at birth; preterm without any other complications $(n=29)$ and uneventful term birth $(\mathrm{n}=43)$. Using the PSS-SR, $28 \%$ of women with preterm pre-eclampsia and women with preterm birth with no other complications met the PTSD profile. The corresponding figure for term pre-eclamptic women and women with uneventful term birth was $17 \%$ and $0 \%$ respectively. Chi-square tests showed that the difference in the prevalence was statistically significant between the four groups $(\mathrm{p}=0.004)$. More specifically, the stratified results by two groups according to gestational age at delivery (ie. the preterm and the term group) showed a difference in prevalence of PTSD profile between the two term groups (a higher prevalence in the term pre-eclampsia group than the uneventful term group), with no difference between two preterm groups (the same prevalence between preterm pre-eclampsia and preterm without complication), indicating that the association between pre-eclampsia and PTSD profile could vary depending on gestation of pregnancy at onset.

Similarly, Baecke et al. [45] assessed two major PTSD symptoms (intrusion and avoidance) using the IES with different levels of exposure; preterm pre-eclampsia $(n=47)$, term pre-eclampsia $(n=18)$, preterm birth but no other medical complications $(n=32)$ and uneventful pregnancy and term delivery $(\mathrm{n}=72)$. A cut-off of 25 in total IES score identified that $44 \%$ of women with preterm pre-eclampsia suffered PTSD symptoms, while the prevalence was $41 \%$ for women with preterm birth but no complications, and $11 \%$ for women with both term pre-eclampsia and uneventful term delivery. The differences between the four groups were statistically significant $(\mathrm{p}<0.001)$. However, stratified results by gestational age at delivery (preterm group and the term group) showed no difference in prevalence in women with and without pre-eclampsia in the same gestational age groups.

Stramrood et al. [44] compared the prevalence of PTSD profile with the PSS-SR, at 6 weeks $\left(t_{1}\right)$ and 15 months $\left(t_{2}\right)$ postpartum in three groups; pre-eclampsia/ HELLP $\left(\mathrm{t}_{1}: \mathrm{n}=57, \mathrm{t}_{2}: \mathrm{n}=44\right)$, preterm premature rupture of membranes (PPROM) $\left(\mathrm{t}_{1}: \mathrm{n}=53 ; \mathrm{t}_{2}: \mathrm{n}=31\right)$ and term uneventful pregnancy $\left(t_{1}: n=65 ; t_{2}: n=62\right)$. The prevalence of PTSD profile was found to be $11 \%$ among women with pre-eclampsia/HELLP and $17 \%$ for women with PPROM at 6 weeks postpartum, which was significantly higher than following uneventful pregnancies in the control group (3\%) $(\mathrm{p}=0.04)$. Stramrood et al's [44] sample included women whose babies died $(n=12)$. When these women were excluded from analysis, the difference between groups (pre-eclampsia/HELLP and PPROM vs. uneventful term groups) was no longer significant at 6 weeks postpartum $(\mathrm{p}=0.06)$ indicating that the death of the baby could have a mediating role. At 15 months postpartum, $11 \%$ of women with pre-eclampsia/
HELLP met the PTSD profile criteria, compared with no controls. The study noted that the low response rate in the PPROM group at 15 months postpartum did not permit any firm conclusions.

Cohen et al. [40] examined the prevalence of PTSD profile among new mothers with a full term singleton infant, using the DTS. In a sample of 200 women, 22 experienced two or more maternal complications and 176 experienced none or one maternal complication during pregnancy and delivery (e.g., heavy bleeding after birth, uterine infection, urinary tract infection, retained placenta). At 8-10 weeks following the birth, telephone interviews with the women revealed that no study participants met their predefined study criteria for PTSDprofile. The prevalence of the 'high postpartum stress' was however high among women who had two more maternal complications (59.1\%) compared to women who had none or one complication (29.6\%). The difference was statistically significant using chi-square test $(\mathrm{p}=0.005)$, but the results should be interpreted with a caution as this dichotomous outcome category (high vs. low postnatal stress) was based on the authors developed a scoring method using the DTS.

In summary, the estimated prevalence of PTSD profile and PTSD symptoms measured by self-rated scales in selected studies varied from $0 \%$ to $44 \%$ following maternal morbidity. Confidence intervals for prevalence were not provided for any of studies, but the wide range of prevalence can be explained by the small sample size in each study. High prevalence of PTSD symptoms (11-44\% at $6-18$ months postnatal) in the study by Baecke et al. [45] may be due to the lower specificity produced by the cut-off of total IES score (total IES $>25$ ) which was selected to define the cases. However, the results of remaining studies indicated that an experience of maternal morbidity, especially of severe or preterm pre-eclampsia could have potentially increased the prevalence of PTSD profile and PTSD symptoms during postpartum period.

\section{What we know}

- The prevalence of PTSD profile and PTSD symptoms up to 2 years postpartum is potentially higher among women who experienced maternal morbidity, especially severe morbidity and/or had a preterm birth (these two are often linked)

What we don't know

- There is no evidence of whether women who experienced severe maternal morbidity are more likely to develop diagnostic PTSD (e.g., meet DSM-IV criteria) 
Is there a statistical relationship between severe maternal morbidity and PTSD (profile/symptoms), and if so, how strong is that relationship?

Five out of the eleven studies examined factors contributing to the presence of PTSD or PTSD profile/symptoms but treated the outcome as a dichotomous variable (eg. presence or absence of PTSD), while six studies examined contributors to the severity of PTSD symptoms by treating the outcome as a continuous variable (ie. total score of selfadministered measurements for PTSD symptoms).

Hoedjes et al. [42] conducted logistic regression analyses for each predictive variable, and showed that the PTSD profile and PTSD symptoms at 6 and 12 weeks postpartum were more frequently present among women who had severe pre-eclampsia than women with mild pre-eclampsia. The prevalence was also higher among younger women, women who had severe preeclampsia, who were delivered by caesarean section, who had a lower gestational age at delivery, a lower birth weight, and among women whose child had been admitted to the neonatal intensive care unit or had died. These variables however were not adjusted for each other. Unadjusted (crude) odds ratio (OR) and statistical significance for each predictors are presented in Table 7.

Baecke et al. [45] reported that preterm pre-eclamptic women had 6.2 times higher odds of having PTSD symptoms than women who had uneventful term delivery. They had also 6.2 times higher odds of PTSD symptoms than women who had term pre-eclampsia, but with a very wide confidence interval (95\% CI: 1.3-30.1). In addition, it was not clear if findings were adjusted for potential confounders as the statistical methods used to provide the odds ratio were not described.

Adewuya et al. [47] conducted a stepwise regression analysis followed by bivariate analysis to identify predictors of PTSD in Nigerian women at 6 weeks postpartum. The results showed the most significant predictors of PTSD were pregnancy-related hospital admission, instrumental delivery, and emergency caesarean section (but not elective), loss of control during childbirth (as measured by the 10-item Labour Agentry Scale at 6 weeks) and manual removal of placenta.

Multivariable logistic regression conducted by Cohen et al. [40] found that women with two or more maternal complications were more likely to have high level of postpartum stress than women with fewer complications after controlling for the effects of other variables (e.g. depression during pregnancy and history of traumatic events) (adjusted $\mathrm{OR}=4.0 ; 95 \% \mathrm{CI}=1.3-12.8$ ). The strongest predictor of high postpartum stress was depression during pregnancy, but with a very wide confidence interval (adjusted $\mathrm{OR}=18.9,95 \% \mathrm{CI}=5.8-62.4$ ). A history of two or more traumatic life events, 'born in Canada' (native Canadian) and higher income had also high odds of having high postpartum stress. The latter two were unexpected findings for the authors who considered "women from developed countries may be more likely to admit to having such symptoms than women from other cultures" (p. 323).

In a sample of women who experienced pre-eclampsia (both preterm and term) and preterm delivery without complication, Engelhard et al. [46] developed a threestep hierarchical multiple regression model to test the relative contribution of predictive variables that were statistically correlated with severity of PTSD symptoms in their bivariate analysis. In the first step, the gestational age of pregnancy on admission was entered in the model which alone accounted for $7 \%$ of the variance in severity of PTSD symptoms. On the second step, peritraumatic reactions (distress and dissociation) were added into the model which accounted for $43 \%$ of the variance. After adjusting for these variables, the association between PTSD symptoms and gestational age was no longer statistically significant. On the final model (the third step), individual psychological characteristics were added: peri-traumatic dissociation $(\beta=.27, \mathrm{P}=0.008)$; negative interpretations of symptoms $(\beta=.40, \mathrm{P}<0.001)$; and thought suppression $(\beta=.25, \mathrm{P}=0.012)$ which together accounted for $61 \%$ of PTSD symptoms among women participants $(\mathrm{F}=34.84, \mathrm{P}=0.001)$. However, all of these psychological characteristics were "based on the subjects' recall of how they felt up to two years previously", and the possibility of recall bias cannot be discounted (p. 263) [46]. Caesarean section and length of hospital stay (used as indicators of severity of pregnancy complication) were not entered in the model these variables were not statistically correlated with severity of PTSD symptoms (CS: $\mathrm{r}=.22, \mathrm{p}=0.07$, length of hospital stay: $\mathrm{r}=.19, \mathrm{p}=0.12$ ). Stramrood et al. [44] performed two-step hierarchical multiple regression analyses to assess factors related to the severity (sum-score) of posttraumatic stress symptoms at 6 weeks postpartum. Variables entered in the first step were history of depression (yes/no) and Beck Depression Inventory (BDI) scores during pregnancy which accounted for $29 \%$ of the variance. In the second step, variables indicative of the wellbeing of both mother and infant were added, that is, death of infant, hospital admission of the infant, birth weight, diagnosis of the mother (pre-eclampsia vs PPROM) and caesarean delivery which accounted for $39 \%$ of the variance. Risk factors that remained statistically significant after controlling for the effects of each variable were self-reported history of depression $(\beta=.23$, $\mathrm{P}=0.007)$, a high BDI score during hospitalization $(\beta=.33$, $\mathrm{P}=0.001)$, and infant death in the postpartum period $(\beta=.29$, $\mathrm{P}=0.001)$.

Similarly, a three step hierarchical multiple regression model in Stramrood et al. [49] showed significant 
predictors of severity of post-traumatic stress symptoms (the TES-B sum-scores) at 2 to 6 months were unplanned caesarean section $(\beta=.11, P<0.01)$, high intensity of pain $(\beta=.11, \mathrm{P}<0.05)$, and low sense of coherence $(\beta=.53, \mathrm{P}<$ 0.001 ) which explained $41 \%$ of the variance in posttraumatic stress symptoms at 2 to 6 months. Initial differences, which were found with non-parametric bivariate analysis in post-traumatic stress symptoms between women who experienced postpartum haemorrhage (>1000 ml) or pre-eclampsia/HELLP and those who did not, disappeared after controlling for the effects of each variable (e.g. mode of delivery).

Ayers [39] examined factors associated with PTSD symptoms, intrusion and avoidance, in a cohort of women in the UK at three time points postpartum; 1 week $(\mathrm{n}=245) ; 6$ weeks $(\mathrm{n}=220)$; and 6 months $(\mathrm{n}=201)$. The study identified women who had severe PTSD symptoms in pregnancy $(\mathrm{n}=18$, as measured with the MMPI-2-PTSD scale) and controlled for the effect during analysis. Using non-parametric statistical tests, the study found factors strongly correlated with avoidance at all three points were subjective birth experience as measured at one week postpartum (the absence of positive emotions, appraising birth as traumatic, lack of control over analgesia and different from how women wanted it to be). On the other hand, key factors correlated with intrusions over 6 months postpartum included pre-existing belief and anxiety. Interestingly, maternal complications had a negative association with PTSD symptoms - women with no labour or birth complications had statistically significantly higher symptoms of intrusion at one week after birth (Mann Whitney, $\mathrm{U}=2619.5, \mathrm{p}<0.05)$ and higher symptoms of avoidance at six months postpartum than women who did (Mann Whitney, $\mathrm{U}=2553, \mathrm{p}<0.05)$. There was no statistical relationship between type of delivery (eg. emergency caesarean section), type of labour onset or complication with the baby and PTSD symptoms (intrusion or avoidance). Spearman's rank correlation coefficient also demonstrated no statistical correlation between the amount of blood loss and either intrusion or avoidance. Blood loss, although initially correlated with women's self-appraisals of their birth as traumatic as measured at 1 week after birth using a 10 $\mathrm{cm}$ visual analogue response scale (Spearman's $\rho .29, \mathrm{p}<$ 0.001 ), was not significant after controlling for negative emotions during birth, lack of positive emotion in birth and mode of delivery. Only the key results relevant to this study are presented in Table 7.

Simple regression and stepwise multiple regression analysis conducted by Creedy [41] revealed that neither maternal delivery complications (self-reported at 4-6 weeks after giving birth) nor antenatal variables (i.e. preparedness, obstetric risk, likelihood of unexpected events, anticipatory anxiety, level of partner support, and state anxiety) were predictive of PTSD symptoms (the IES total score) at 4-6 weeks among women in Australia $(\mathrm{n}=499)$ who had a term delivery with no serious risk of obstetric complication during pregnancy (figures not presented for maternal complication). Factors associated with PTSD symptoms were women's retrospective selfreport of obstetric intervention $(\beta=.35, \mathrm{P}<0.001)$ which looked at the cumulated impact of five key variables (ie. emergency caesarean section $(\beta=.20, P<0.0001)$, forceps delivery $(\beta=.17, \mathrm{P}<0.0001)$, post-delivery pain $(\beta=.16$, $\mathrm{P}<0.0001)$, vacuum delivery $(\beta=.14, \mathrm{P}<0.002)$ and diagnosis for the baby - a congenital condition or some other medical complication on delivery $(\beta=.10, \quad \mathrm{P}<0.02))$. The perception of maternity care (measured at 4-6 weeks postpartum) also had a strong negative association with PTSD symptoms $(\beta=-.39, \mathrm{p}<0.001)$ indicating lower the perception of maternity care, the higher the risk of PTSD symptoms. The study further developed hierarchical regression models to determine whether the relationship between obstetric intervention and PTSD symptoms at 4-6 weeks postpartum was mediated by perception of care. The model identified that perception of care was not a mediator but had an additive effect on the PTSD symptoms; in other words, both obstetric intervention $(\beta=.26, P<0.001)$ and perception of care $(\beta=.32, \mathrm{P}<0.001)$ directly contributed to the outcome. Creedy also examined contributors to PTSD symptoms at 3 months postpartum $(\mathrm{n}=141)$ among women who described a stressful birth event and had reported at least three trauma symptoms at 4-6 weeks using the IES. Multiple regression analyses showed that level of preparedness for labour and delivery (as measured in pregnancy by a 5 point Likert scale self-assessment question 'how well prepared do you feel for childbirth?') $(\beta=.-16, P=0.03)$, the perception of intrapartum care $(\beta=.42, \mathrm{P}=0.0001)$ and obstetric intervention $(\beta=.15, \mathrm{P}<0.05)$ were associated with PTSD symptoms at 3 months postpartum that accounted for $24.5 \%$ of variance. None of specific obstetric intervention (e.g. emergency caesarean section, forceps delivery) was statistically associated with PTSD symptoms at this time point.

Linear regression models in Lev-Wiesel et al. [43] showed that neither delivery complications nor high risk pregnancy were statistically associated with PTS symptoms (PSS-I total score) at 6 months after delivery among 1071 women in Israel. Instead, higher levels of subjective pain and distress during delivery assessed at 1 month after delivery $(\beta=.51, \mathrm{p}<0.001)$, depression during pregnancy $(\beta=.15, \mathrm{p}<$ $0.001)$ and history of life traumatic events $(\beta=.08, \mathrm{p}<0.01)$ were found to be predict variables of PTS symptoms.

Sorenson and Tschetter [48] reported a positive correlation between maternal complications and perinatal trauma symptoms (yes/no) measured at 6-7 months postpartum using the author developed measurement (point-biserial correlation coefficient: $\mathrm{rpbs}=0.28$ ). 
In summary, results for the relationship between severe maternal morbidity and PTSD (profile/symptoms) from selected studies were inconsistent. This could be explained by the following factors: selection bias due to a lack of definition of maternal morbidity, unreliable data sources, the sample only included relatively healthy women (e.g. term delivery), or data unadjusted for potential confounders. However, four studies [42,44-46] which had clear definitions of maternal morbidity and reliable data sources tended to indicate that severe maternal morbidity could potentially increase the risk of postpartum PTSD symptoms. Of these, three studies conducted analysis only in a sample of patients with preeclampsia/PPROM or preterm delivery without including medically uncomplicated women $[42,44,46]$. The results indicated that the association between maternal morbidity and PTSD symptoms may not be direct but possibly mediated by other factors such as distress and/ or neonatal conditions (e.g. prematurity, death). However, due to the small sample size of these studies $(\mathrm{n}<$ 180), definite conclusions cannot be drawn.

\section{What we know}

- The available evidence about the relationship between maternal morbidity and PTSD/PTSD symptoms is inconsistentand varies between studies

- The relationship is possibly mediated by other factors such as fetal/neonatal conditions (e.g. prematurity, death) andperitraumatic dissociation.

\section{What we don't know}

- There is no robust evidence to show whether there is a direct relationship between severe maternal morbidity and PTSD/PTSD symptoms after controlling for other predictors and potential confounders (e.g. mode of delivery, pre-existing psychological morbidity)

Does the type of severe maternal morbidity affect the relationship between severe maternal morbidity and PTSD (profile/symptoms)?

Only five studies examined a specific maternal complication; pre-eclampsia [42,44-46] and blood loss [39]. As described earlier, pre-eclampsia, particularly severe preeclampsia and preterm pre-eclampsia increased PTSD profile or PTSD symptoms postpartum, while no correlation was found between the amount of blood loss and PTSD symptoms [39]. In Ayers' study, the range of blood loss was not reported, and it is uncertain if there were any cases of severe obstetric haemorrhage. Postpartum haemorrhage was examined by Cohen et al. [40] and Creedy [41], but it was clustered together with other complications (e.g. urinary tract infection, site unspecific infection). In summary, from evidence currently available, this question cannot be answered.

What we know

- There is some evidence that pre-eclampsia might be linked to PTSD profile/PTSD symptoms

- There is insufficient evidence to inform a relationship between obstetric haemorrhage and PTSD profile/PTSD symptoms

What we don't know

- There is no evidence to determine whether the type of severe maternal morbidity affects the relationship between severe maternal morbidity and PTSD/PTSD symptoms

\section{Discussion}

This paper describes a systematic review of the association between women experiencing severe maternal morbidity during labour, at the time of giving birth or within the first week following birth, and post-traumatic stress disorder. Findings are based on a comprehensive literature search and rigorous critical appraisal of included studies.

No high quality quantitative studies were identified to determine whether women who experienced severe maternal morbidity are more likely to develop PTSD or traumatic stress symptoms than women who did not. Our review however found a potential higher risk of PTSD following severe maternal morbidity. The prevalence of PTSD profile among pre-eclamptic women from 6 weeks up to two years postpartum was $5 \%-44 \%$. This appeared to be a higher percentage than that found in an earlier systematic review on PTSD following childbirth in general. For example, Olde et al. [4] found that the prevalence of PTSD among mothers who had successful birth outcomes (including normal births and births by caesarean section, but excluding pregnancy complications) was estimated to be approximately $3 \%$ to $6 \%$ at around six weeks postpartum, decreasing to around $2 \%$ at six months postpartum. Similarly, a narrative review by Ayers [63] suggested a prevalence of $0 \%$ $7 \%$ of PTSD within one year after giving birth, while the figure was higher for at-risk groups (i.e., premature birth or stillbirth), up to $26 \%$ at one month postpartum. These are the estimates from different populations, but provide some idea that the rate may also be higher for women who experienced severe maternal morbidity.

An earlier systematic review by Tedstone and Tarrierb [64] on PTSD following other medical illnesses (e.g., myocardial infarction, acute lung injury and stroke) suggested 
that the link between the severity of the illness and the development of PTSD is not always straightforward. Recent prospective studies in low-income countries [65] showed that the development of psychological distress following severe maternal morbidity was mediated by perinatal loss. Our review also identified the possibility of an indirect relationship in which the association between maternal morbidity (i.e. pre-eclampsia) and post-traumatic stress symptoms differed according to a third factor such as gestational age at delivery, baby's condition (e.g. prematurity, death) and negative interpretations of symptoms. However, due to the methodological limitations in selected studies, possible pathways towards PTSD or mechanisms underlying the relationship could not be fully explained. Insufficient evidence was available to compare the outcomes following different types of severe maternal morbidity.

\section{Limitations of the Review}

This review included studies from developed and developing countries. As health care systems differ across countries, careful interpretation is required as findings from one country cannot be generalised to others. Studies were excluded if they did not include outcomes of severe maternal morbidity. However, some conditions, such as stillbirth and caesarean section, could be a consequence of severe maternal morbidity. As these are potential mediators or contributors to PTSD [66-68], excluding them might have limited understanding of the complexities of PTSD/PTSD symptoms following severe maternal morbidity. As we only included studies written in English, publication bias is a possibility, as positive findings are more likely to be published in English [69].

\section{Implications for practice}

Despite the absence of robust evidence regarding the relationship between severe maternal morbidity and PTSD/ PTSD symptoms, the results of our review suggest that maternal morbidity, particularly severe cases involving poor neonatal outcomes, may be followed by PTSD and its symptoms. It is crucially important that clinicians and policy makers are aware of possible PTSD symptoms in response to severe maternal morbidity since the incidence of severe maternal morbidity is increasing in many western countries [26,28]. Early and timely recognition of women at risk and appropriate referral is necessary, as this may reduce the duration of treatment $[46,70]$ and potentially reduce subsequent long term burden of PTSD both to the individual and society [71].

\section{Further research}

A comprehensive evaluation of the potential association between severe maternal morbidity and subsequent PTSD and PTSD symptoms is timely and important to inform the safety and quality of maternity care. There is an urgent need for prospective research with large sample sizes and appropriate recognition of important confounders. These studies will also require: 1 ) well-defined definitions of severe maternal morbidity; 2) sophisticated measurement of PTSD and its symptoms; and 3) inclusion of potential mediators or moderators (e.g., neonatal outcomes, subjective perception, recovery environment) in analysis to better understand mechanisms underlining the relationship between severe maternal morbidity and PTSD and PTSD symptoms. In addition, there is a need for greater openness and transparency in study reporting.

\section{Conclusion}

The psychiatric impact of severe maternal morbidity remains uncertain, but this review suggests a potential relationship between severe maternal morbidity and PTSD and PTSD symptoms. Well-designed studies are necessary to understand the relationship and the mechanism underlying the association in order to minimise the longer term psychiatric impact of severe maternal morbidity. In line with NICE guidance [71], signs of PTSD symptoms following severe maternal morbidity should be monitored over time to make sure problems are identified as early as possible to enable timely, appropriate and effective care to meet individual needs to be implemented.

\section{Endnotes}

${ }^{a}$ Severe pre-eclampsia was defined as 'pre-eclampsia and at least one of the following: severe blood pressure elevation defined by systolic blood pressure $\geq 160 \mathrm{~mm}$ $\mathrm{Hg}$ and/or diastolic blood pressure $\geq 110 \mathrm{~mm} \mathrm{Hg}$, severe proteinuria ( 5 or more grams in $24 \mathrm{~h}$ ), HELLP syndrome defined by a thrombocyte count $\leq 100 \times 109 / \mathrm{l}$, and/or ASAT and ALAT above $30 \mathrm{U} / \mathrm{l}$, eclamptic convulsions, or fetal growth restriction' (p127) [42].

\section{Additional files}

Additional file 1: Prisma 2009 Cheklist.

Additional file 2: Excluded studies and the reason for the exclusion.

Additional file 3: Methodological quality of selected studies.

\section{Competing interests}

The authors declare that they have no competing interests.

Author's contributions

MF developed the review with the support of DB and JS. The search strategy was completed by MF, data extraction, analysis and methodological assessments were made by MF, DB and JS. All authors contributed to the review. All authors contributed to the manuscript. All authors read and approved the final manuscript. 


\section{Acknowledgements}

The authors thank Derek Cooper, Sarah Beake, Kirstie Coxon and Annette Briley for their comments on the draft article. The authors also thank Marlene Blackstock for her literature searching support.

\section{Author details}

${ }^{1}$ King's College London, Florence Nightingale School of Nursing and Midwifery, James Clerk Maxwell Building, 57 Waterloo Road, London SE 8WA, UK. 'King's College London, Division of Women's Health, Women's Health Academic Centre KHP, North Wing, St. Thomas' Hospital, 1 Westminster Bridge Road, London SE1 7EH, UK.

Received: 15 July 2012 Accepted: 22 October 2012 Published: 10 November 2012

\section{References}

1. American Psychiatric Association: Diagnostic and statistical manual of mental disorders: DSM-IV-TR. 4th edition. Washington, DC: American Psychiatric Association; 2000.

2. Bailham D, Joseph S: Post-traumatic stress following childbirth: a review of the emerging literature and directions for research and practice Psychology. Health Med 2003, 8(2):159-168.

3. Slade P: Towards a conceptual framework for understanding posttraumatic stress symptoms following childbirth and implications for further research. J Psychosom Obst Gyn 2006, 27(2):99-105.

4. Olde E, van der Hart O, Kleber R, van Son M: Posttraumatic stress following childbirth: A review. Clin Psychol Rev 2006, 26(1):1-16.

5. Ayers S: Thoughts and emotions during traumatic birth: a qualitative study. Birth 2007, 34(3):253-263.

6. Brockington I: Postpartum psychiatric disorders. Lancet 2004, 363(9405):303-310.

7. Halligan SL, Murray L, Martins C, Cooper PJ: Maternal depression and psychiatric outcomes in adolescent offspring: A 13-year longitudinal study. J Affect Disorders 2007, 97(1-3):145-154.

8. Kumar RC: Anybody's child": severe disorders of mother-to-infant bonding. Brit J Psychiat 1997, 171:175-181.

9. Parfitt YM, Ayers S: The effect of post-natal symptoms of post-traumatic stress and depression on the couple's relationship and parent-baby bond. J Reprod Infant Psychol 2009, 27(2):127-142.

10. Hay DF, Pawlby S, Sharp D, Asten P, Mills A, Kumar R: Intellectual problems shown by 1-year-old children whose mothers had postnatal depression. J Child Psychol Psychiatry 2001, 42(7):871-889.

11. Sharp D, Hay DF, Pawlby S, Schmucker G, Allen H, Kumar R: The impact of postnatal depression on boys' intellectual development. J Child Psychol Psychiatry 1995, 36(8):1315-1336.

12. Pawlby S, Sharp D, Hay D, O'Keane V: Postnatal depression and child outcome at 11 years: The importance of accurate diagnosis. $J$ Affect Disorders 2008, 107(1-3):241-245.

13. MacArthur C, Winter HR, Bick DE, Lilford RJ, Lancashire RJ, Knowles H, Braunholtz DA, Henderson C, Belfield C, Gee H: Redesigning postnatal care: a randomised controlled trial of protocol-based midwifery-led care focused on individual women's physical and psychological health needs. Health Technol Assess 2003, 7(37):1-98.

14. Waterstone M, Wolfe C, Hooper R, Bewley S: Postnatal morbidity after childbirth and severe obstetric morbidity. Bjog-an Int J Obstet Gynaecol 2003, 110(2):128-133.

15. Kessler RC: Posttraumatic stress disorder: The burden to the individual and to society. J Clin Psychiatry 2000, 61:4-14.

16. Andersen LB, Melvaer LB, Videbech $P$, Lamont RF, Joergensen JS: Risk factors for developing post-traumatic stress disorder following childbirth: A systematic review. Acta Obstet Gynecol Scand 2012, doi:10.1111/j.1600-0412.2012.01476.x.

17. Ayers S: Delivery as a traumatic event: prevalence, risk factors, and treatment for postnatal posttraumatic stress disorder. Clin Obstet Gynecol 2004, 47(3):552-567.

18. Waterstone M, Bewley S, Wolfe $C$ : Incidence and predictors of severe obstetric morbidity: case-control study. Br Med J 2001, 322(7294):1089-1093.

19. Wen SW, Huang L, Liston R, Heaman M, Baskett T, Rusen ID, Joseph KS, Kramer MS, Grp MHS, Sy CPS: Severe maternal morbidity in Canada, 1991-2001. Can Med Assoc J 2005, 173(7):759-764.
20. Say L, Souza JP, Pattinson RC, Mortality WHOWGM: Maternal near miss - towards a standard tool for monitoring quality of maternal health care. Best Pract Res Clin Obstet Gynaecol 2009, 23(3):287-296.

21. Ronsmans C, Filippi $\vee$ : Reviewing severe maternal morbidity: learning from women who survive life threatening complications. In Beyond the numbers Reviewing maternal deaths and complications to make pregnancy safer. Edited by. Geneva: World Health Organisation; 2004.

22. Vais A, Bewley S: Severe acute maternal morbidity. In A Textbook of postpartum hemorrhage A comprehensive guide to evaluation, management and surgical intervention 1. Edited by B-Lynch C. Kirkmahoe: Sapiens; 2006:339-352.

23. World Health Organization: The conceptual framework for the International Classification for Patient Safety Version 1.1. 2009. http://www.who.int/ patientsafety/taxonomy/icps_full_report.pdf

24. Say L, Pattinson RC, Gulmezoglu AM: WHO systematic review of maternal morbidity and mortality: the prevalence of severe acute maternal morbidity (near miss). Reprod Health 2004, 1(1):3.

25. Penney G, Kernaghan D, Brace V: Severe maternal morbidity - the Scottish experience 2003/05. In The Confidential Enquiry into Maternal and Child Health (CEMACH) Saving Mothers' Lives - 2003-2005 The 7th Report on Confidential Enquiries into Maternal Deaths in the United Kingdom. Edited by Lewis G. London: CEMACH; 2007.

26. Norman J: 2011. In Saving Mothers' Lives: Reviewing Maternal Deaths to Make Motherhood Safer 2006-2008. Edited by Lewis G.: BJOG; 2011:1-203. 118 (Suppl. 1).

27. NHS Quality Improvement Scotland: Scottish Confidential Audit of Severe Maternal Morbidity 2008: 6th Annual Report. Edinburgh: NHS Quality Improvement Scotland; 2010

28. van Roosmalen J, Zwart J: Severe acute maternal morbidity in high-income countries. Best Pract Res Clin Obstet Gynaecol 2009, 23(3):297-304

29. Callaghan WM, MacKay AP, Berg CJ: Identification of severe maternal morbidity during delivery hospitalizations, United States, 1991-2003. Am J Obstet Gynecol 2008, 199(2).

30. Pallasmaa N, Ekblad U, Gissler M: Severe maternal morbidity and the mode of delivery. Acta Obstet Gynecol Scand 2008, 87(6):662-668.

31. Knight M: Preeclampsia: increasing incidence but improved outcome? Am J Hypertens 2008, 21(5):491.

32. Knight M: Appendix 2A: Summary of United Kingdom Obstetric Surveillance System (UKOSS) Report on near-miss studies. In Maternal and Child Enquiries (CMACE). Saving Mothers' Lives: reviewing maternal deaths to make motherhood safer: 2006-08. The Eighth Report on Confidential Enquiries into Maternal Deaths in the United Kingdom. BJOG 2011, 118(1):191-195.

33. Beck CT: Post-traumatic stress disorder due to childbirth: the aftermath Nurs Res 2004, 53(4):216-224.

34. Elhai JD, Frueh BC, Gold PB, Hamner MB, Gold SN: Posttraumatic Stress, Depression and Dissociation as Predictors of MMPI-2 Scale 8 Scores in Combat Veterans with PTSD. J Trauma Dissociation 2003, 4(1):51-64.

35. Friedman MJ, Keane TM, Resick PA: ebrary I: Handbook of PTSD: science and practice. New York: Guilford Press; 2007.

36. American Psychiatric Association: Diagnostic and statistical manual of mental disorders (3rd ed.). Washington, DC: American Psychiatric Association; 1980

37. Public Health Resource Unit England: Critical Appraisal Skills Programme (CASP). England: Public Health Resource Unit; 2006.

38. Moher D, Liberati A, Tetzlaff J, Altman DG, The PG: Preferred Reporting Items for Systematic Reviews and Meta-Analyses: The PRISMA Statement. PLoS Med 2009, 6(7):e1000097.

39. Ayers S: Post-traumatic stress disorder following childbirth. Thesis (Ph.D.). University of London; 1999

40. Cohen MM, Ansara D, Schei B, Stuckless N, Stewart DE: Posttraumatic stress disorder after pregnancy, labor, and delivery. J Womens Health 2004 13(3):315-324.

41. Creedy DK: Birthing and the development of trauma symptoms: incidence and contributing factors. Griffith University; 1999.

42. Hoedjes M, Berks D, Vogel I, Franx A, Visser W, Duvekot JJ, Habbema JDF, Steegers EAP, Raat H: Symptoms of post-traumatic stress after preeclampsia. J Psychosom Obstet Gynecol 2011, 32(3):126-134.

43. Lev-Wiesel R, Chen R, Daphna-Tekoah S, Hod M: Past traumatic events: Are they a risk factor for high-risk pregnancy, delivery complications, 
and postpartum posttraumatic symptoms? Journal of Womens Health 2009, 18:119-125.

44. Stramrood C, Wessel I, Doornbos B, Aarnoudse J, van den Berg P, Schultz WW, van Pampus M: Posttraumatic stress disorder following pre-eclampsia and PPROM; A prospective study with 15 months follow-up. J Psychosom Obstet Gynecol 2010, 31:96-96.

45. Baecke M, Spaanderman ME, van der Werf SP: Cognitive function after pre-eclampsia: an explorative study. J Psychosom Obstet Gynaecol 2009, 30(1):58-64

46. Engelhard IM, van Rij M, Boullart I, Ekhart TH, Spaanderman ME, van den Hout MA, Peeters LL: Posttraumatic stress disorder after pre-eclampsia: An exploratory study. Gen Hosp Psychiatry 2002, 24(4):260-264.

47. Adewuya AO, Ologun YA, Ibigbami OS: Post-traumatic stress disorder after childbirth in Nigerian women: prevalence and risk factors. BJOG 2006, 113(3):284-288.

48. Sorenson DS, Tschetter L: Prevalence of negative birth perception, disaffirmation, perinatal trauma symptoms, and depression among postpartum women. Perspect Psychiatr Care 2010, 46(1):14-25.

49. Stramrood CAl, Paarlberg KM, In't Veld EMJH, Berger LWAR, Vingerhoets AJJM, Schultz WCMW, Van Pampus MG: Posttraumatic stress following childbirth in homelike- and hospital settings. J Psychosom Obstet Gynecol 2011, 32(2):88-97.

50. American College of Obstetricians and Gynecologists (ACOG): Diagnosis and management of preeclampsia and eclampsia. ACOG practice bulletin. Number 33. Int J Gynaecol Obstet 2002, 77(1):67-75

51. Creedy DK, Shochet IM, Horsfall J: Childbirth and the development of acute trauma symptoms: Incidence and contributing factors. Birth-Issues in Perinatal Care 2000, 27(2):104-111.

52. Sheehan DV, Lecrubier $Y$, Sheehan $\mathrm{KH}$, Amorim $\mathrm{P}$, Janavs J, Weiller $\mathrm{E}$, Hergueta T, Baker R, Dunbar GC: The Mini-International Neuropsychiatric Interview (MINI): The development and validation of a structured diagnostic psychiatric interview for DSM-IV and ICD-10. J Clin Psychiatry 1998, 59:22-33.

53. Foa EB, Riggs DS, Dancu CV, Rothbaum BO: Reliability and validity of a brief Instrument for assessing post-traumatic stress disorder. J Trauma Stress 1993, 6(4):459-473.

54. Davidson JRT, Book SW, Colket JT, Tupler LA, Roth S, David D, Hertzberg M, Mellman T, Beckham JC, Smith RD, et al: Assessment of a new self-rating scale for posttraumatic stress disorder. Psychol Med 1997, 27(1):153-160.

55. Hovens JE, Bramsen I, van der Ploeg HM: Self-rating Inventory for Posttraumatic Stress Disorder: Review of the psychometric properties of a new brief Dutch screening instrument. Percept Motor Skill 2002, 94(3):996-1008.

56. Hovens JE, van der Ploeg HM, Bramsen I, Reuling IE: Test-retest reliability of the self-rating inventory for posttraumatic stress disorder. Psychol Rep 2000, 87(3 Pt 1):735-737.

57. Wijma K, xOOF desquist J, Wijma B: Posttraumatic stress disorder after childbirth: a cross sectional study. J Anxiety Disord 1997, 11(6):587-597.

58. Horowitz M, Wilner N, Alvarez W: Impact of event scale - measure of subject stress. Psychosom Med 1979, 41(3):209-218.

59. Sorenson DS: Post-traumatic stress disorder inventory. In Brookings. Edited by. SD: South Dakota State University (unpublished); 2000.

60. Wilson JP, Keane TM: Assessing psychological trauma and PTSD. 2nd edition. New York: London: Guilford; 2004

61. Stramrood CAl, Veld EMJ HI't, Van Pampus MG, Berger LWAR, Vingerhoets AJJM, Schultz WCMW, Van Den Berg PP, Van Sonderen ELP, Paarlberg KM: Measuring posttraumatic stress following childbirth: a critical evaluation of instruments. J Psychosom Obst Gyn 2010, 31(1):40-49.

62. Wohlfarth TD, van den Brink W, Winkel FW, ter Smitten M: Screening for Posttraumatic Stress Disorder: an evaluation of two self-report scales among crime victims. Psychol Assess 2003, 15(1):101-109.

63. Ayers S, Joseph S, McKenzie-McHarg K, Slade P, Wijma K: Post-traumatic stress disorder following childbirth: current issues and recommendations for future research. J Psychosom Obstet Gynaecol 2008, 29(4):240-250.

64. Tedstone JE, Tarrier N: Posttraumatic stress disorder following medical illness and treatment. Clin Psychol Rev 2003, 23(3):409-448.

65. Fottrell E, Kanhonou L, Goufodji S, Behaque DP, Marshall T, Patel V, Filippi V: Risk of psychological distress following severe obstetric complications in Benin: the role of economics, physical health and spousal abuse. Br J Psychiatry 2010, 196(1):18-25.
66. Hughes $P$, Turton P, Hopper E, Evans CDH: Assessment of guidelines for good practice in psychosocial care of mothers after stillbirth: a cohort study. Lancet 2002, 360(9327):114-118.

67. Ryding EL, Wijma B, Wijma K: Posttraumatic stress reactions after emergency cesarean section. Acta Obstet Gynecol Scand 1997, 76(9):856-861

68. Turton $P$, Hughes $P$, Evans CD, Fainman D: Incidence, correlates and predictors of post-traumatic stress disorder in the pregnancy after stillbirth. Br J Psychiatry 2001, 178:556-560.

69. Egger M, Smith GD, Schneider M, Minder C: Bias in meta-analysis detected by a simple, graphical test. Br Med J 1997, 315(7109):629-634.

70. Poel YHM, Swinkels P, de Vries JIP: Psychological treatment of women with psychological complaints after pre-eclampsia. J Psychosom Obstet Gynaecol 2009, 30(1):65-72.

71. National Institute for Clinical Excellence (NICE): Post-traumatic stress disorder (PTSD): The management of PTSD in adults and children in primary and secondary care. Clinical Guideline 26.; 2005. http://guidance.nice.org.uk/CG26/ Guidance/pdf/English.

doi:10.1186/1471-2393-12-125

Cite this article as: Furuta et al:: A systematic review of the relationship between severe maternal morbidity and post-traumatic stress disorder. BMC Pregnancy and Childbirth 2012 12:125.

\section{Submit your next manuscript to BioMed Central and take full advantage of:}

- Convenient online submission

- Thorough peer review

- No space constraints or color figure charges

- Immediate publication on acceptance

- Inclusion in PubMed, CAS, Scopus and Google Scholar

- Research which is freely available for redistribution

Submit your manuscript at www.biomedcentral.com/submit
C Biomed Central 